"نشريه علوم زراعى ايران"

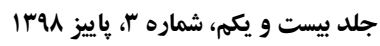

مقاله موروى

نقش تنظيم كنندهاى رشد در افزايش عملكرد كياهان زراعى در شرايط شور: از تئورى تا عمل

The role of plant growth regulators in enhancing crop yield under saline

conditions: from theory to practice

هادى بير استه انوشه' و يحيى امام؟

جكيده

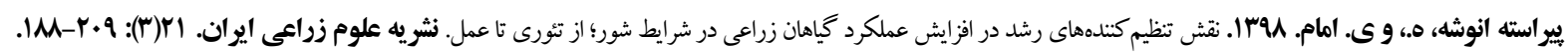

تشديد روند شور شدن منابع آب و خاكى، باعث افزايش توجه به يزوهش هاى مرتبط با راهكارهاى بهبود عملكرد كياهان زراعى

در شرايط شور شده است. بر اساس كزارشهاى منتشر شده، سابقه يزوهشها بيرامون شـناخت جنبـهــاى مختلـف تـنش شـورى و روشهاى افزايش تحمل كياهان به شورى در جهان به بيش از يكك قرن مىرسـد. راهكارهـاى متفـاوت و متعـددى بـراى افززايش عملكرد كياهان زراعى در شرايط شور هيشنهاد شده است كه يكى از آنها استفاده از تنظيم كنندههاى رشد كياهى اسـت. استفاده از تنظيم كنندههاى رشد از دها • آو آغاز شده و فروش جهانى سالانه آنها حدود //1 ميليارد دلار است. انواع تنظيم كنــدهــاى رشد حاوى حدود • ع نوع ماده فعال هستند كه بهصورت منفرد يا تركيبى به عنوان تنظيم كننده رشد مورد استفاده قرار ممىيرنسد. از مهمترين تنظيم كنندههاى رشد مىتوان بـه اكسـينها، سـايتوكينينهـا، جيبرلينهـا، اتسيلن، آبسيز يك اسـيد، براسينواسـتروئيدها، ساليسيليك اسيد، كلرمكوات كلرايد، باكلوبوترازول، جاسمونيك اسيد، آسكوربيك اسيد، ترياكونتانول، استريوكالاكتونهـا، نيتريـك اكسيد، بلى آمينها و هورمونهاى يِيتدى كياهى اشاره كرد. تز ارشهاى فراوانى در مورد افزايش كميـت و كيفيست محصـول و بهبود تحمل به شورى در كياهان زراعى در اثر مصرف تنظيم كنندههاى رشد وجود دارد، اما اغلب اين ئزوهشها در محسيطهـاى كنترل شده (شرايط خارج از مزرعه) و بهصورت يكساله، انجامشده است كه همين موضوع باعث عدم كاربردى شـدن نتـايج اغلـب اين يزوهشها شده است. در اين مقاله اثر مصرف تنظيم كنندهاى رشد بر بهبود عملكرد كياهان زراعى در شرايط شور، با تاكيد بـر شرايط مزرعه، مورد بروسى قرار كرفته است.

وازههاى كليدى: برايمينك بذر، تحمل، تنش شورى و هورمونهاى كياهى.

تاريخ دريافت: IraV/Tr/lQ ا- استاديار مركز ملى تحقيقات شورى، سازمان تحقيقات، آموزش و ترويج كشاورزى، يزد، ايران (مكاتبه كننده) (يست الكترونيكك: h.pirasteh.a@gmail.com r- r- استاد دانشكده كشاورزى دانشكاه شيراز 
را كشــت كـــد. در صـورتى كـه خــاكك قليـايى باشـــ

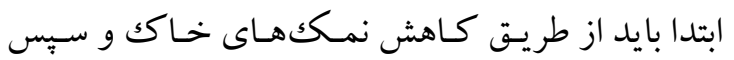

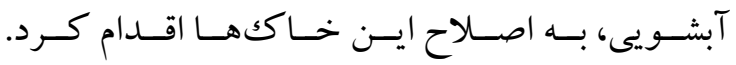

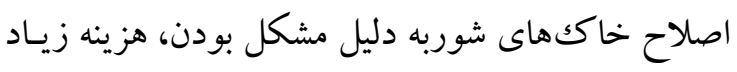

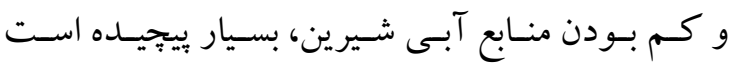
(Pirasteh-Anosheh et al., 2014a)

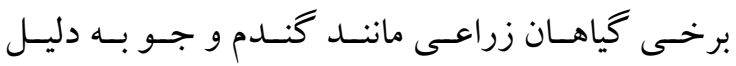

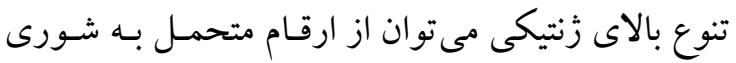
براى كشت استفاده كرد. مشكل استفاده از ارقام متحمل

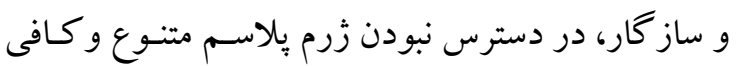
اسـت (Ranjbar and Pirasteh-Anosheh, 2017). در

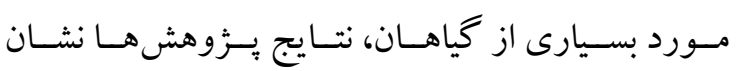

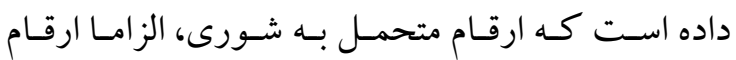
مناسـب و برمحصـول بـراى شـرايط شـور نمسىباشـند (Ranjbar et al., 2018) مسى تـوان برخى گياهـان شوردوسـت نظيـر سـاليكورنيا

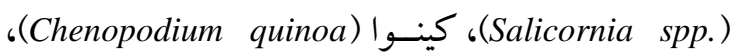
كوشـيا (Bassia spp.)، آتــييلكس (Atriplex spp.)، ارزن بِادزهرى (Panicum antidotale) را با هدف توليـ علوفه، دانه يا روغن كشت كرد. در سطوح بايين شورى

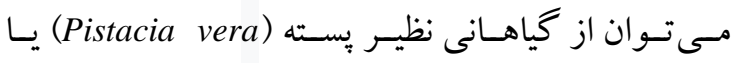
منداب (Eruca sativa) كه تحمل نسبى به شورى دارنــ نيسز اسـتفاده كـرد (Ranjbar et al., 2018). كثـت لهنت

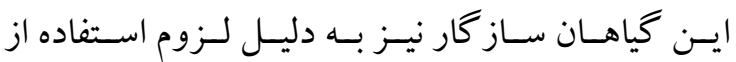

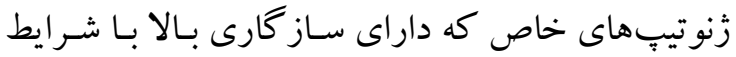

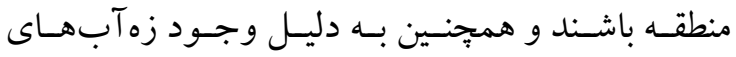

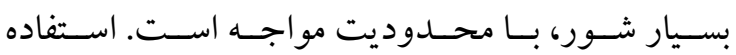

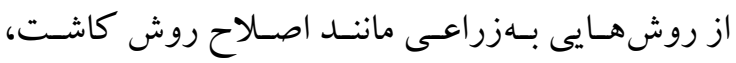

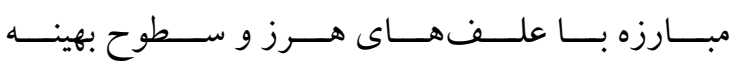

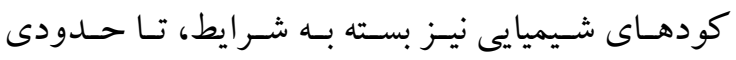

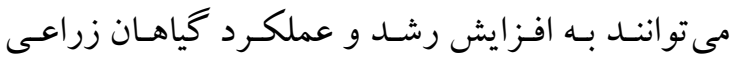
كمك كنند (Ranjbar and Pirasteh-Anosheh, 2017). يكى از راهكـارى آسـان، كـم هزينه و زودبـازده،

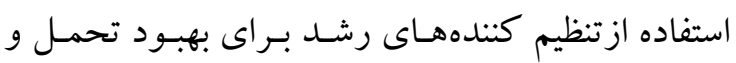

\section{مقدمه}

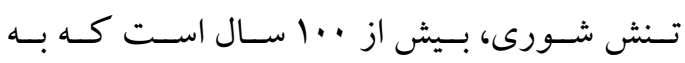
عنوان يكى از مهم ترين عوامل كاهش توليد محصولات

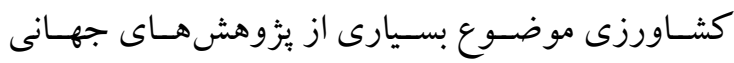

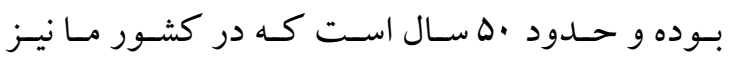

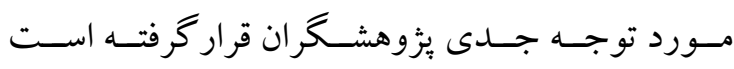
(Ranjbar and Pirasteh-Anosheh, 2015) از نظر اقليمى در زمره مناطق خشك و نيمه خشك قـرار

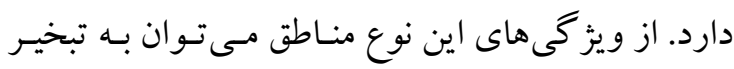

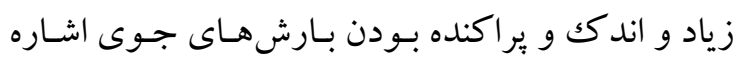
كرد كه باعث تجمع نمككها در قشر سـطحى خـاككهـا

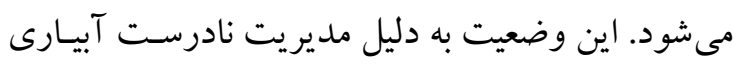

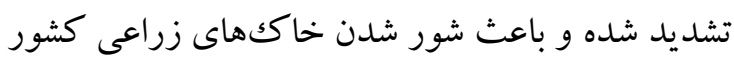

مى شود (Ranjbar and Pirasteh-Anosheh, 2017). شورى رشد گياهان را به دو صورت تحت تأثير قرار

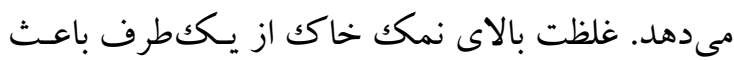

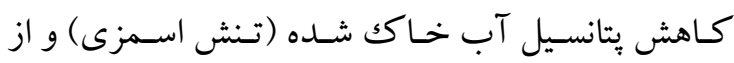
طرف ديخر در گياه ايجاد سميت مى كند (سميت يونى)

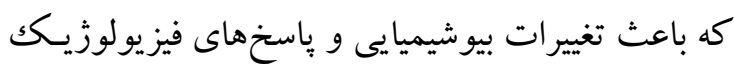
در گياه مس شـود (Pirasteh-Anosheh et al., 2017). مسموميت يونى در اثـر تجمـع يـونهـاى خـاص بـهويزه سديم، باعـث اخـتلال در واكـنش هــاى متابوليكك كيـاه

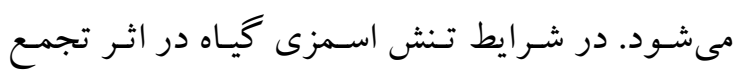

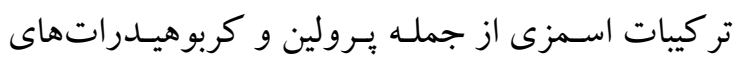

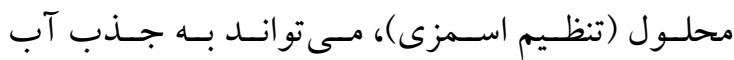

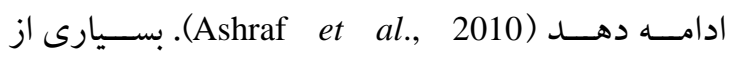

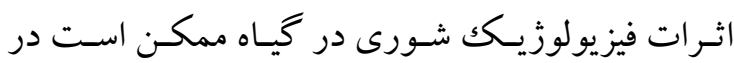

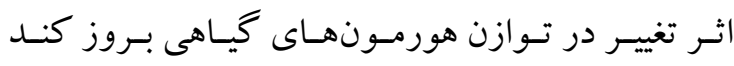

.(Ashraf and Foolad, 2005) با توجه به شدت شورى و عوامل اقليمى، روشهـاى

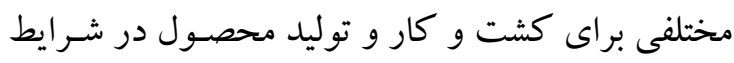

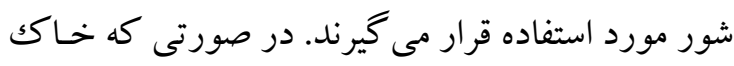

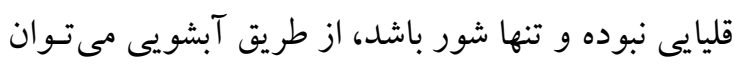

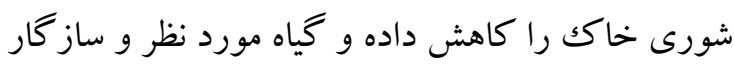




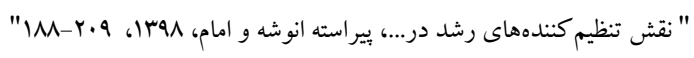

دارد تا به غلظت هر كـدام از آنهـا بـه تنهـايى. كـاربرد

تنظيم كنتدهاى رشد بهطور شايان توجهى باعـث ايجـاد تعـادل هورمسونى در گياهـان در شــرايط شـور مىشـود

.(Ashraf et al., 2010; Pirasteh-Anosheh et al., 2013)

استفاده سيستمى از تنظيم كنندههاى رشـد از دهـه .ب19 ميلادى آغاز شـده و روز بـه روز بــ اهميـت و مصـرف آنهـا افزووده مسىشـود (Rademacher, 2015). ميـزان مصرف جهانى تنظيم كنــدهــاى رشـد در سـال r. r. ميلادى نزديكك به 19/V هزار تن ماده خالص بـوده و در

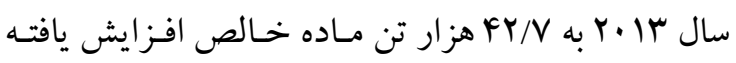
است و بيش بينى شده است كه تا سال •.r. · به بـيش از ها هز ار تن ماده مـؤثر خواهــ رسـيد (Moradi, 2016).

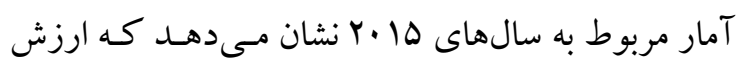
بازار تنظيم كنندهاى رشـد كيـاهى حسدود ب/ F ميليـارد دلار و فروش سالانه آنها حدود ب/ إيليارد دلار بـوده است (Rademacher, 2015). بيشبينى قيمـت آتى ايسن محصولات، ارزش آتى بـازار را بـيش از شـش ميليـارد دلار بر آورد كرده است (Moradi, 2016). در حدود ·F ماده فعال وجود دارند كـه بـه صسورت
افـزايش توليــ كياهـان زراعـى در شـــايط شـور اسـت

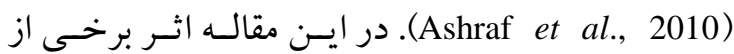
تنظيم كنندههاى رشد بر رشد و عملكرد گياهـان زراعى در شرايط تنش شورى ارائه شده و سـبس رهيافتهـاى عملى براى استفاده از اين تر كيبـات مـورد بررسـى قـرار كر فته است. تنظيم كنندهاى رشد

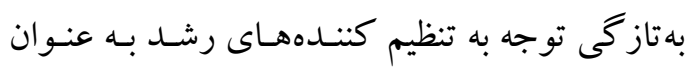

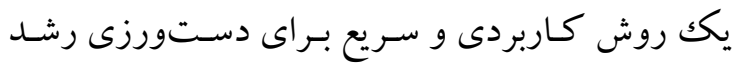
كياهان در شرايط تنش شورى افزايش يافته است. يكى

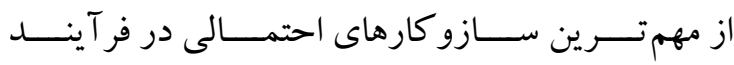

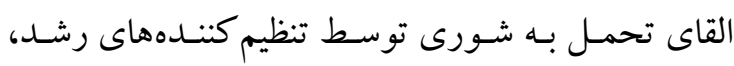
تاثير آنها بر تعادل هورمونى كياه است. ينج دسـته مهـم

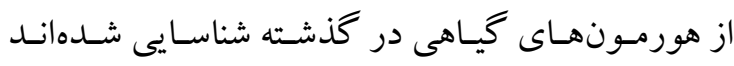
(جدول () كه بـه تـدريج بـر تعـداد آنهـا افزوده شـده اسـت. نتـايج يـزّوهش هـا نشـان داده اسـت كـه تعـادل هورمونى كياه در شرايط تنش شورى بـه هـــم مى خـورد (Ashraf and Foolad, 2005; Hayat et al., 2010) منفى جنين تغييرى، بيشتر به غلظت نسـبى آنهـا بســـى

$$
\text { جدول ا- دسته بندى هورمونهاى مهم گياهى و اثر كلى آنها بر كياهان }
$$

Table 1. Classification of the important plant hormones and their general effects on plants

\begin{tabular}{|c|c|c|c|c|c|c|c|}
\hline & & $\begin{array}{c}\text { جوانهزنى } \\
\text { Germination }\end{array}$ & $\begin{array}{c}\text { فنولوزى } \\
\text { Phenology }\end{array}$ & $\begin{array}{c}\text { كلدهى } \\
\text { Flowering }\end{array}$ & $\begin{array}{c}\text { نمو } \\
\text { Development }\end{array}$ & ريزش بركى و ميوه & $\begin{array}{c}\text { خواب بذر } \\
\text { Seed dormancy }\end{array}$ \\
\hline Gibberellins & جيبرلينها & $\checkmark$ & $\checkmark$ & $\checkmark$ & $\checkmark$ & $x$ & $x$ \\
\hline Auxins & اكسينها & $x$ & $\checkmark$ & $\checkmark$ & $\checkmark$ & $\checkmark$ & $x$ \\
\hline Cytokinins & سايتو كينينها & $\checkmark$ & $\checkmark$ & $\checkmark$ & $\checkmark$ & $\times$ & $\times$ \\
\hline Ethylene & اتيلن & $x$ & $x$ & $\checkmark$ & $\checkmark$ & $\checkmark$ & $\times$ \\
\hline Abscisic acid & آبسيزيكك اسيد & $\checkmark$ & $\times$ & $\times$ & $\times$ & $\checkmark$ & $\checkmark$ \\
\hline
\end{tabular}

ساليسيليككاسـيد SA Salicylic acid; SA)، كلرمكــوات كلرايـد (Chlormequat chloride; CCC)، جاسـمونيك (بك

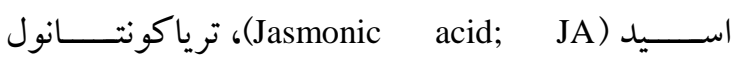
(Triacontanol)

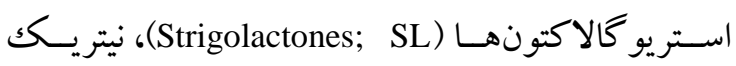
اكسيد (Nitric oxide; NO) ، بِلى آمينهـا (Polyamines)
منفرد يا تر كيبى به عنوان تنظيم كنتـده رشـد كيـاهى مـورد اسـتفاده قــرار مى كيرنـــ(Rademacher, 2015). Cytokinins; (Auxins; Aux) (كسين هايتو كينين هـا Cyt (Ethylene)

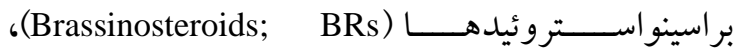




$$
\text { "نشريه علوم زراعى ايران"، جلد بيست و يكم، شماره با، باييز شهسا }
$$

جـوبى انتقـال مسى يابنــد. مهـم تـرين تـاثيرات ايسن دسـه از هورمونها شكستن خـواب بـــر و آغـاز رشـد سـاقه از طريست طويـل شــدن سـلول و تقســم سـلولى اسـت (Bari and Jones, 2009) از شناخته شده تـرين انسواع ايسن كروه هورمـونى اسـت

.(Peleg and Blumwald, 2011) اتيلن كه به نام هورمون بيرى نيـز شـناخته مسىشـود،

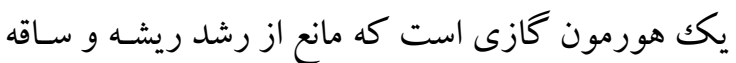

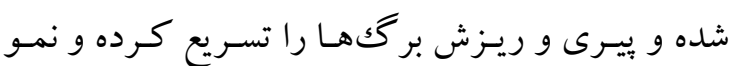
جوانههاى جانبى را نيز به تأخير مى اندازد. اتيلن مى تواند

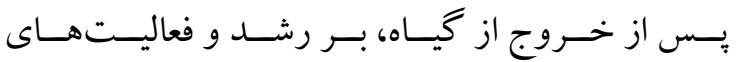
فيزيولوزيكك گياهان مجاور نيز تأثير بـذارد. مهـمترين نقشهايى كه به اتيلن نسبت داده مىشود، تحريك بلوغ

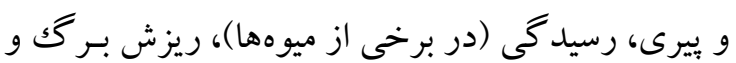
مر گك گل ها مىباشد (Davies, 2013). آبسيزيككاسيد

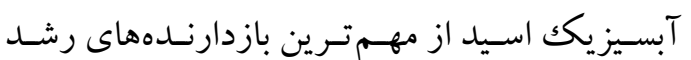
كياهى است و در فر آيندهاى زيادى از جمله ركود بـذر بـر و جوانه و ريـزش انـدامهاى گيـاهى نقـش مهمسى دارد. عوامل محيطى تنشزا مانند شورى، با افزايش آبسيزيك اسيد و كاهش جيبرلينها باعث القاى خـواب مسىشـوند (Peleg and Blumwald, 2011) (ين هورمون به كونهاى ائ فعال، در بازدارندگى رشد و نمو، تحريك مر گك بـر و خواب بذر، ياسخ كياهان بـه تـنشهـا و كنتـرل بـاز و بسته شدن روزنههـا و تنظيم رطوبـت نسـبى كيـاه نقـش

دارد (Davies, 2013).

بر اسينواستروئيدها

براسينو اســـتروئيدها، نـــوعى از يــــى هيدرو كســى

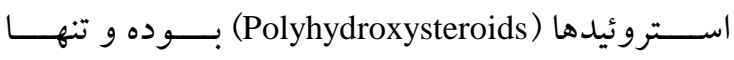

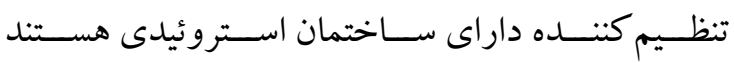
كـه بـه عنـوان ششـمين دسـته از (Ashraf et al., 2010)

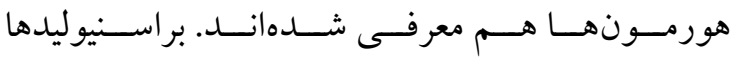

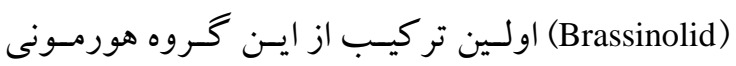

و هورمـونهـاى ييتيـدى گيـاهى (Peptide hormones)، تنظيم كنندههاى رشد شناختهشـدهاى هسـتند كـه باعـث بهبود عملكرد و كيفيت محصولات زراعى مىشوند. در ادامه اين مقاله به معرفى اجمالى و مهممترين اثـرات ايـن تنظيم كنندها برداخته شده است.

اكسينها

اكســينهــا اولــين هورمـونهــاى گيــاهى هســنـد

كه كشف شدند. از مهم تـرين انـواع اكسـينهـا اينـدول اسـتيكك اسـيد (Indole acetic acid; IAA)، اينــدول بوتيريـك اسـيد (IBA Indole butyric acid; IBA)، نفتالناستيكك اسيد (Naphthalene acetic acid; NAA) و فيل اسـتيكك اسـيد (Phenyl acetic acid; PAA) هسـتند

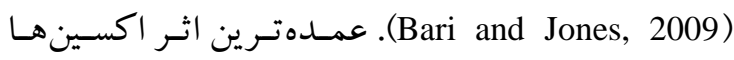
تحريك رشد اوليه از طريق طويل شدن سلول و افزايش سرعت تقسيمات سـلولى، تحريـك غالبيـت انتهايى بـــ صورت رشد ناحيه نمـوى انتهايى كيـاه و جلـو گيرى از رشد جوانههـاى جـانبى و جهـت دههى رشـد انـدامهـاى كياهى است (Moori et al., 2012). سايتو كينين ها سايتو كينين ها گروهى از هورمونهاى گياهي هستيند كه به طور ويثه در تحريكك تقسيم سلولى كياهان نقـش لهـ مهمهـى را ايفــا مـى كنتــــ (Moori et al., 2012).

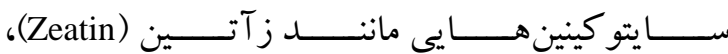
بنزيـلـل آمينويورين (Benzyl aminopurine) و كــاينتين (Kinetin)

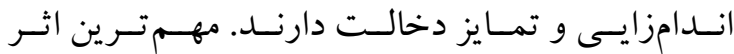

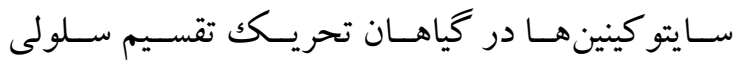
در ريشه و ساقه، رشـد ثانويسه از طريـق ضـخيم شـدن و

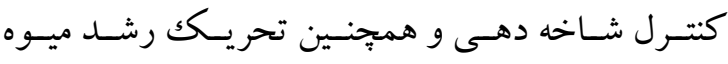
مىباشد (Bari and Jones, 2009). جيبرلين ها

جيبرلين ها گروهى از هورمونهـا هسـتند كه عمـدتا

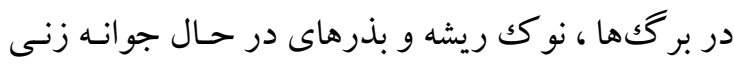

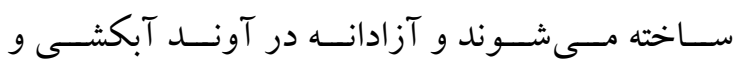




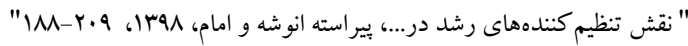

و قابــل حــل در آبـ بــوده كـــه از آن بـــه عنـــوان

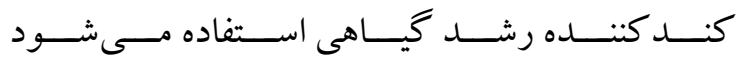
Pirasteh-Anosheh and Emam, 2010) تنظيم كنتـدكى رشـد كلرمكـوات كلرايـد نخسـتين بـار در دهــه ،1991، در طيــف وســيعى از كياهــان نشــان

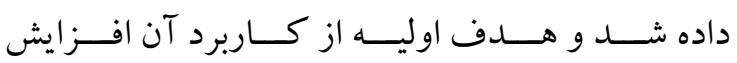

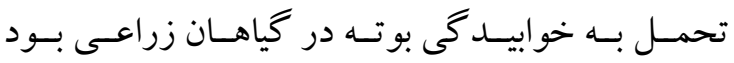

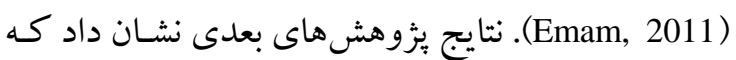

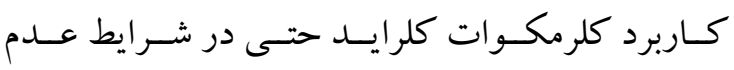
خو ابيـدكى هـم باعـث افز ايش عملكـرد دانـه مسىشـود .(Pirasteh-Anosheh and Emam, 2017) كلرمكــوات كلرايــد بـــا اخــتلال در ابتـــاى مســير بيوســنتز جيبرليـك اســــ مــانع از فعاليـت آنــزيم انـت كـائورون سـينتاز (Ent-kaurene synthase) شـده (Adler and Wilcox, 1987) بوته مىشود و به همين علت به عنوان تنظيم كنــده ضــ جيبر لينى ناميده مىشود (Emam, 2011). جاسمونيك اسيد جاسمونات ها از نظر بيوسـنتزى، از لينولئكك اسـيد طى يكك سرى واكنش ساخته مهى شـوند. ايسن تر كيبات در بسـيارى از گونسههـاى گيـاهى بـراى مقابلـه بـا

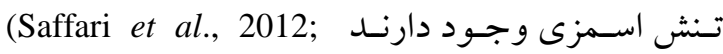
. جاسـمونيكك اسـيد بـا تغيير در . جahabi et al., 2016) بيوسنتز يروتئين، محتـواى مـالون دى آلدهيـد و فعاليـت آنتى اكسيدانها نقـش حفـاظتى در برابـر تـنش هـا دارد (Yun-xia et al., 2010) (جاسمونيك اسـيد بـا تحريـك توليــ يـروتئين هـاى دفـاعى از گيـاه در برابـر تسنشهـاى شورى و خشكى محافظت مى كند. بعـلاوه جاسـمونيك ن. اسيد بر جوانه زنى بذر، ذخيره يـروتئين در بــر و رشــ

ريشهها تاثير مى كذارد (Pakar et al., 2016).

سديم نيتروير اكسايد

سديم نيترو ير اكسايد با رها كردن نيتريـك اكسيد،

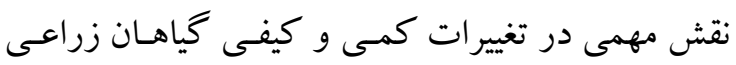
دارد. نيتريك اكسيد يكك راديكـال گـازى نسـبتا يايسـار

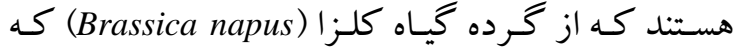
توسط زنبورها جمع آورى شده بود استخراج شـده و بـــ همـين دليـل وازه براســينو در ابتـداى نـام ايسن كـروه هورمونى قرار كرفت. اثرات متفاوتى از جمله تحريـك طويل شدن و تقسـيم سـلولى، زمسين كرايسى، تحمـل بـهـ تنش هاى محيطى و تمايز آوند جوبى، بازدارند

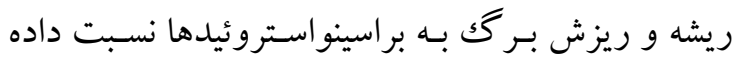

شدهاند (Bari and Jones, 2009).

\section{ساليسيليك اسيد}

ساليسيليك اسيد يكى از اسـيدهاى آلى اسـت كـه كاربردهــاى وســيعى در داروســازى و صــنعت دارد.

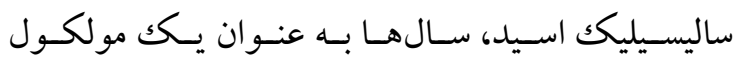

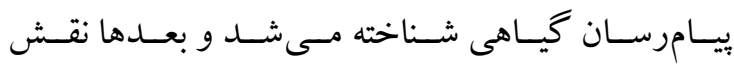
تنظيم كنند كى آن نيز مشـخص شـد. ايسن تنظيم كنتـده

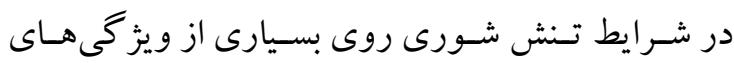

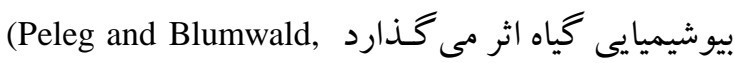
2011; Pirasteh-Anosheh and Emam, 2018b) يـزّوهشهـا نشـان داده اسـت كـه ساليسـيليكك اسـيد بـا تاثير بـر زنهـاى كيـاهى، طيـف وسـيعى از ويز خـىهـا

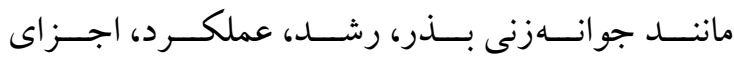
عملكـــد، فيزيولـوزى و بيوشـيمى كيـاه را، بـه ويـزّه در شرايط تنش شـورى، تحـت تـاثير مثـت قـرار مـىدهــ

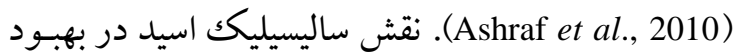
ويز كى هاى بيوشيميايى گياه مانند محتو اى يروتئينهـاى

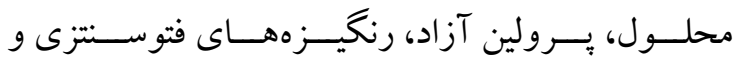

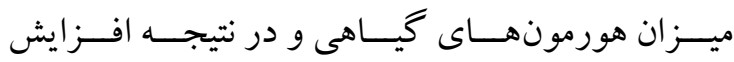
عملكـرد در شـرايط تـنش شـورى در برخـى از كياهـان

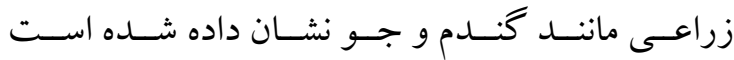

.(Pirasteh-Anosheh et al., 2017)

كلرمكوات كلر ايد

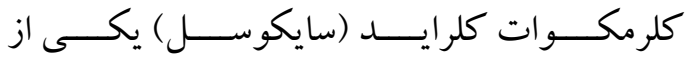

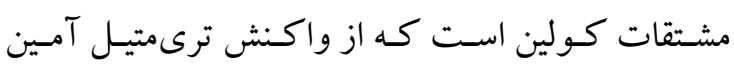

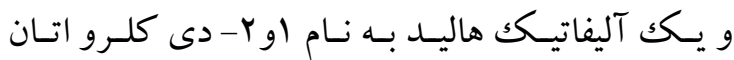

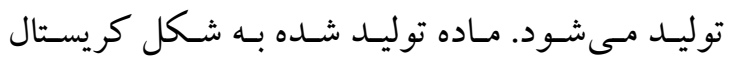


نمو گيـاه از طريـق كنتـرل كسـترش و تقسـيم سـلولى و

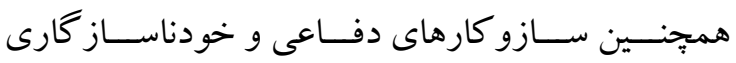
كــرده ايفــا مــى كنتـــ (Bari and Jones, 2009). ترياكونتانول (Triacontanol) يكك الكل جرب است كـه به عنوان يكك تحريكك كننـده رشـد، بـه ويـزه در توليـد ياجوش هاى جديــ در خـانو اده كَل سـرخيان نيـز عمـل مى كند. اين ماده در يونجـه، مـوم زنبـور عسـل و برخسى

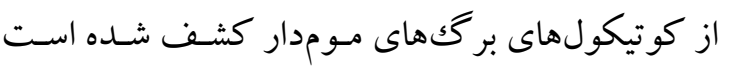

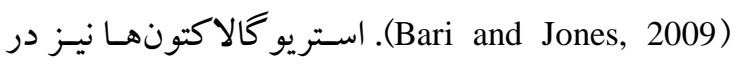
شـاخه دهــى و رشــد كياهــان نقـش دارنــــ و ســنتز آنها توسط هورمـون آبسـيزيكك اسـيد تنظيم مسى شـود

.(Peleg and Blumwald, 2011)

ييشتيمار (يرايمينع) بذر با تنظيم كنندههاى رشد

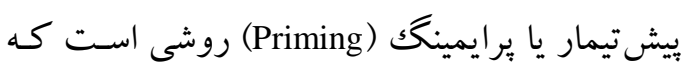
در آن بذر به مدت معينى درون يك محلول بـا بتانسيل ئرسيل

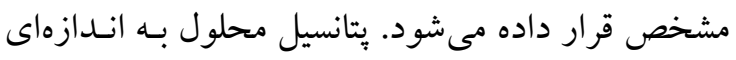

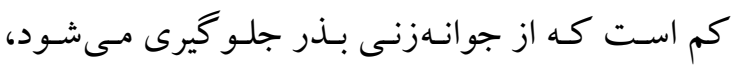

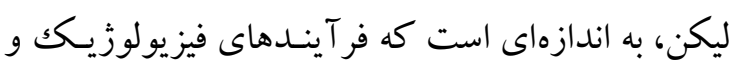

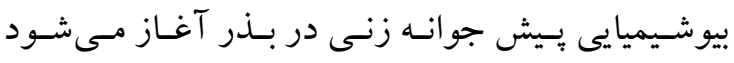

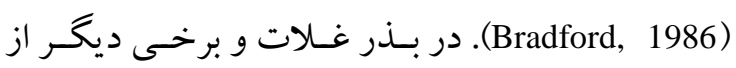
كياهان زراعى، توليد آنزيم آلفا آميلاز در لايه آلـورون توسط هورمونهاى جيبـرلين و آبسيزيك اسـيد كنترل مسىشود (Sun and Gubler, 2004). ساليسيليكك اسـيد اثرى مشابه اثر آبسيزيك اسيد دارد و بازدارنده جيبرلين

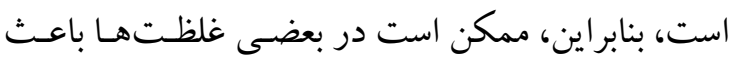

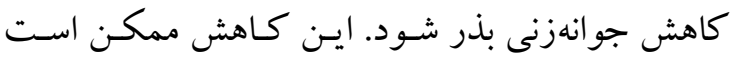

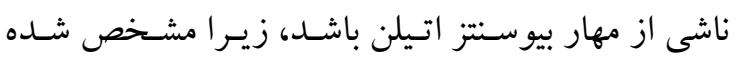
است كه ساليسيليك اسيد نقش مهار كنندگى در بيوسنتز

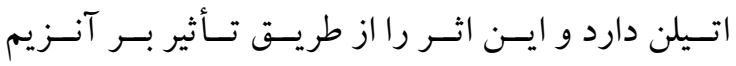
Aminocyclopropane-1-carboxylic acid synthase اعمال مىنمايد (Jafar et al., 2012). يِيشتيمـار گيـاه بـا

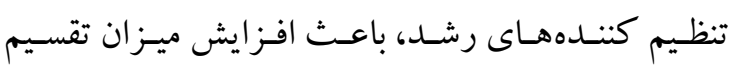

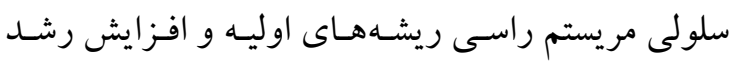

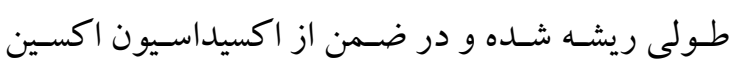

است كه به عنـوان مولكـول بيـام رسـان در باسـخ هـاى

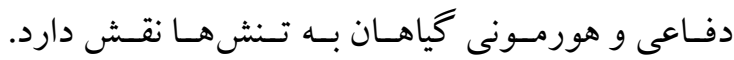

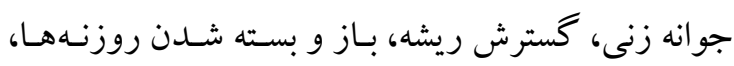

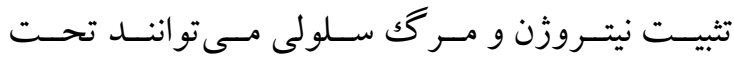

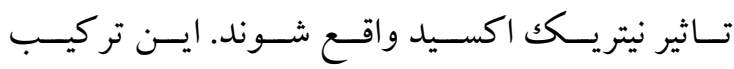

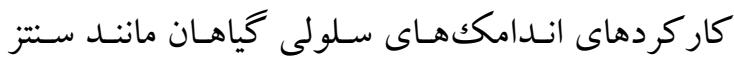
ATP در كلرويلاست و ميتو كندرى را نيز تنظيم مى كنــ (Delledonne et al., 1998)

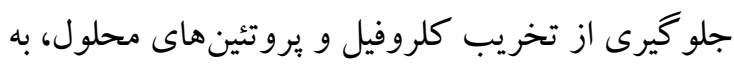

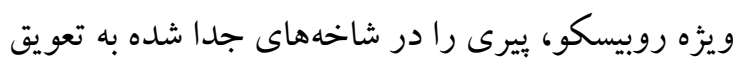

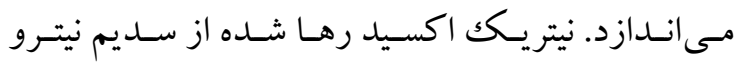
يراكسايد در كنترل باز و بسته شدن روزنههـا نقـش دارد (Mata and Lamattina, 2001) كاركردهاى سديم نيترو يراكسايد تحريك سيستم آنتى

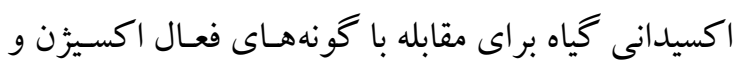

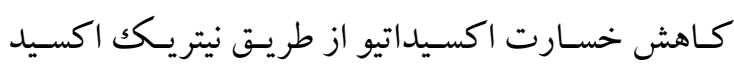
است (Nasibi et al., 2009).

\section{ساير تنظيم كنندهایى رشدكياهى}

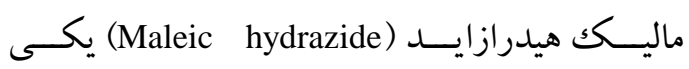

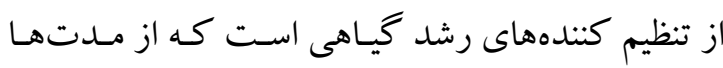

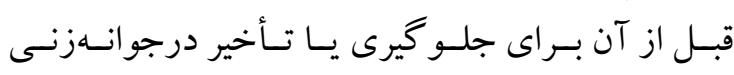

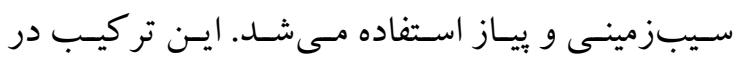

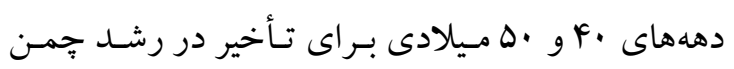

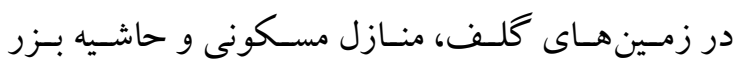

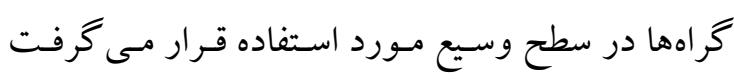

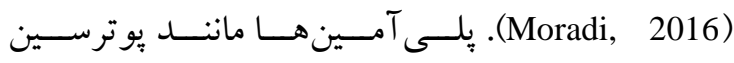
(Putrescine) نيز كه به تاز گى نقش تنظيم كنند

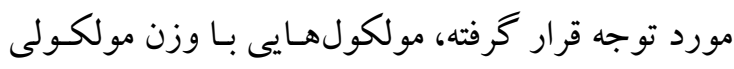

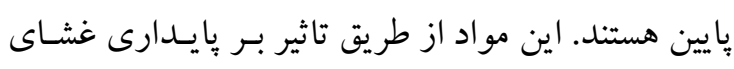

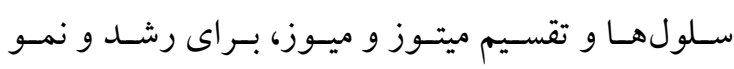

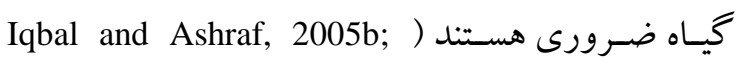

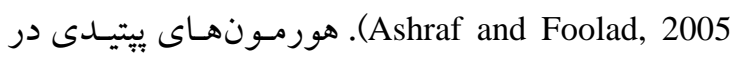

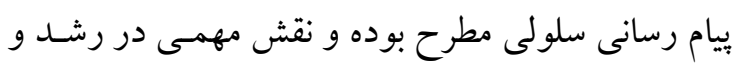


آسـكوربيكك اسـيد و ساليسيليككاسـيد نـه تنها باعـث

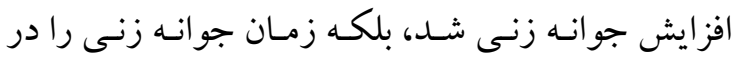
شرايط شـور نيـز كـاهش داد. تيمارهـاى فـوق همجِنسين

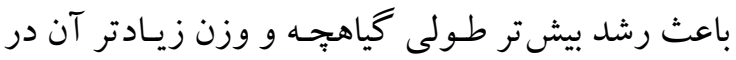
مقايسه با بذور تيمار نشده در شرايط شور شدئد

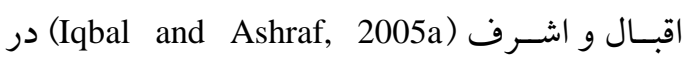
آزمايشى اثر بيش تيمار بذر كندم با هورمونهاى بنزيـل

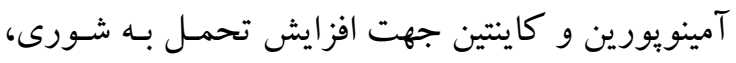
رشد، عملكرد و تغييرات بيوشيميايى درون بذر را را مـورد

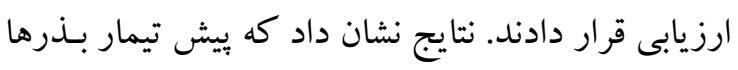
با كاينتين بيشترين تأثير را بر بهبود رشد و و عملكرد دانه

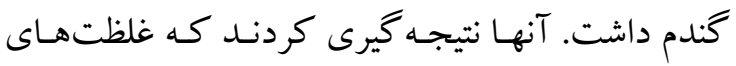
متوسط كاينتين اثر معنى دارى بـر بهبـود عملكـرد دانـه كندم در شرايط شور داشت، هر جند سازو كارى كه در

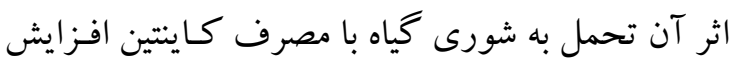
مى يابد، مشخص نشده است.

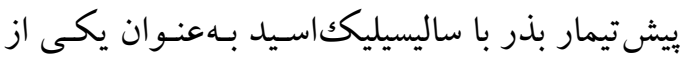

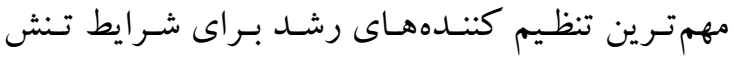

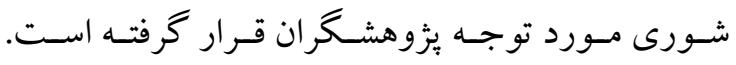
هاشمى و همكاران (Hashemi et al., 2015) نشان دادنــ

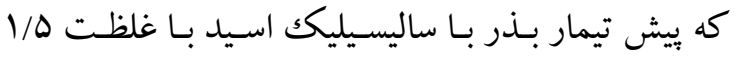
ميلى مـولار، باعـث افز ايش تعـداد دانه در سـنبله، وزن

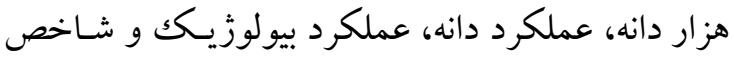

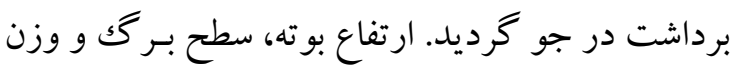

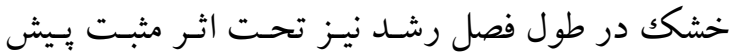

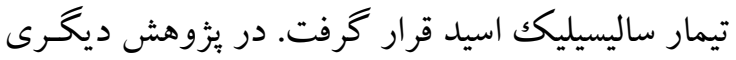
نشان داده شد كه بيش تيمـار (Hashemi et al., 2018a) بذر جو بـا ساليسيليكك اسـيد بخشى از افزايش غلظـت

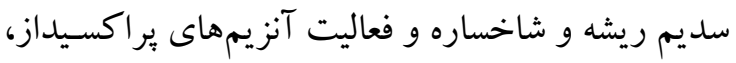

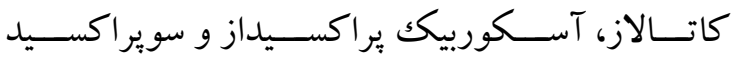
ديسمو تاز و كاهش غلظت بِتاسيم ريشـه و شاخسـاره در اثـر تسنش شـورى را جبـران كـرد. هاشـمى و همكـاران طلى آزمايش ديخرى گزارش (Hashemi et al., 2018c)

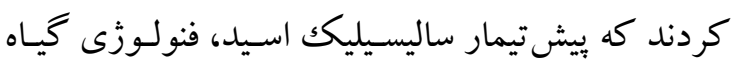

جلو گيرى مى كند (Fariduddin et al., 2018).

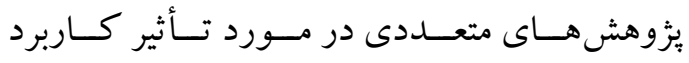

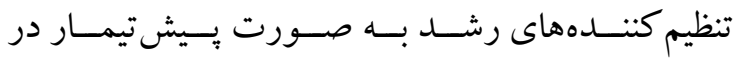

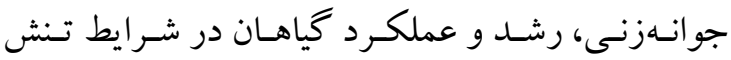

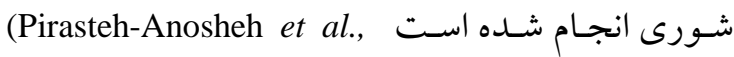
2011; Hashemi et al., 2012; Jafar et al., 2012; Hashemi et al., 2015; Delaviz et al., 2016; PirastehAnosheh et al., 2016b; Pirasteh-Anosheh et al., 2016c; Pirasteh-Anosheh and Emam, 2017; Hashemi et al., 2018a; Hashemi et al., 2018c; هanjbar et al., 2019)

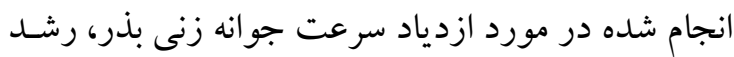

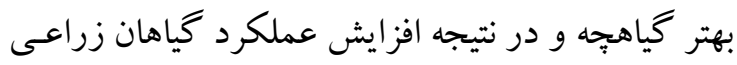
در هر دو شرايط شور و غيرشور در بذرهاى بيش تيمار (Ashraf et al., شده با تنظيم كنندهاى رشد وجود دارد 2010; Hayat et al., 2010; Pirasteh-Anosheh et al., 2014a; Pirasteh-Anosheh et al., 2016c; Ranjbar and Pirasteh-Anosheh, 2017)

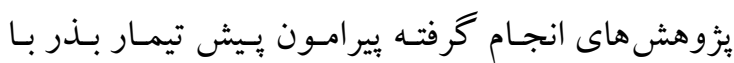

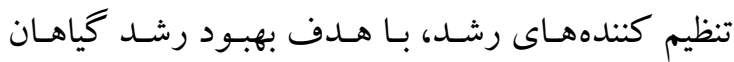
زراعى، ارائه شده است. جعفر و همكـاران (Jafar et al., 2012) اثر سـه نـوع استه يسـيش تيمـار هورمــونى (ساليسيليككاسـيد، كـاينتين و

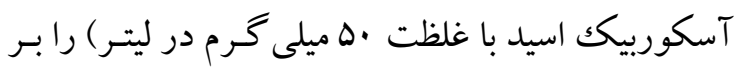
طيف وسيعى از صفات كمى و كيفى دو رقم گنـدم در

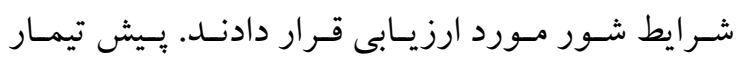

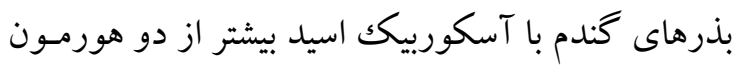
ديكر باعث بهبود رشد، عملكرد و كيفيـت هـر دو رقـم

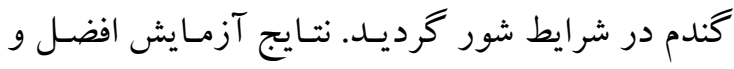

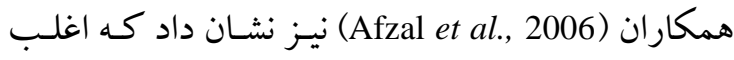
تيمارهـاى هورمسونى مـورد اسـتفاده (آبسـيزيكك اسـيد،

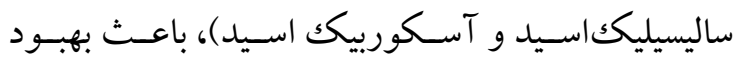
جوانه زنسى بـذور كنـدم در شـرايط شـور شـدند. تيمـار

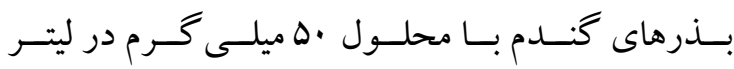




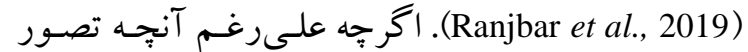
مسىشـود، كياهــان شـورزى تحمـل بسـيار بــالايعى بــه

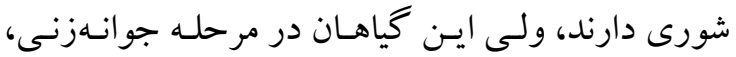

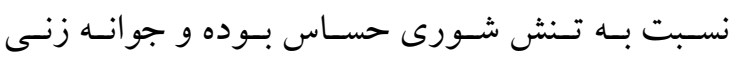
مطلوب بذر آنها در شـورىهـاى بسـيار بـايين صـورت مى كيرد (Ranjbar et al., 2019). نتايج يـروهش اونخًار نشـان داد كـه غلظـت · ا ميلسى مـولار (Ungar, 1977) جيبرليك اسيد باعث افزايش ميزان جوانه زنسى بــرهاى

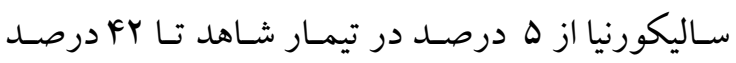
كرديــ. خـان و وبـر (Khan and Weber, 1986) نيـز كزارش دادند كه جوانهزنى در ساليكورنيا از هه درصــ در تيمار Y درصد كلريد سـديم تـا VD درصـد در تيمـار جيبرليكك اسيد افزايش يافت، تيمـار جيبرليكك اسـيد بـا غلظت يكك ميلى مولار نتايج رضايت بخش تـرى نسـبت به غلظـت // • ميلـى مـولار داشـت. نجفى و همكـاران نيـز نشـان دادنــد كـه تيمـار (Nadjafi et al., 2006) جيبرليك اسيد اثر معنىدارى بر درصد و سرعت جوانسه زنى بــر دو گونـه باريجـه (Ferula gummosa) و مـريم نخودى (Teucrium polium) داشت. رنجبـر و همكاران

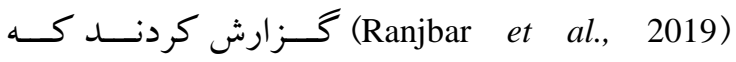

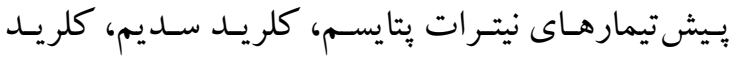
كلسيم و جيبرليككاسيد جوانسزنسى بـذور سـاليكورنيا را افزايش مىدهند و بيشترين تاثير مربـوط بـه غلظـتهـاى

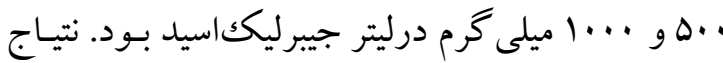
اين يـزّوهش نشـان داد كـه يـيش تيمـار جيبرليـك اسـيد باعث افـزايش آسـتانه تحمـل بـه شـورى سـاليكورنيا در مرحله جوانهزنسى مسى گـردد؛ بـه طـورى كـه در شـرايط

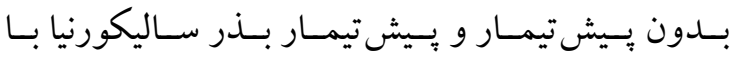

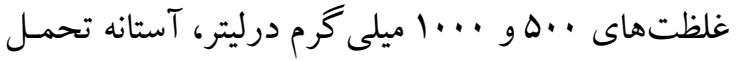

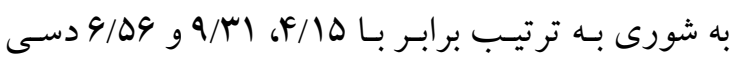

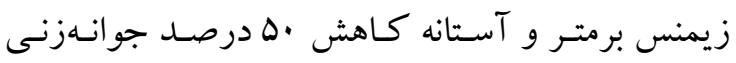
وس/ • r, اثر مثبت بيش تيمار بذر بـا سـاير هورمونهـا نيـز بـر

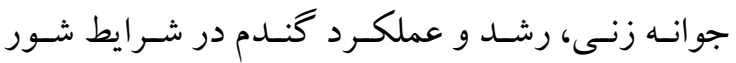

جو را نيز تحت تاثير قرار داد، به نحوى كه فاصله زمانى كاشـت تـا مرحلـه غـلاف رفـتن (آبسـتنى)، كاشـت تـا كلدهى و كاشت تا رسيدگى رادر هر دو شـرايط شـور

$$
\text { و غير شور افزايش داد. }
$$

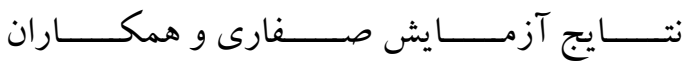

(Saffari et al., 2012) متيـل جاســمونات و ساليسـيليككاسـيد باعــث بهـــود

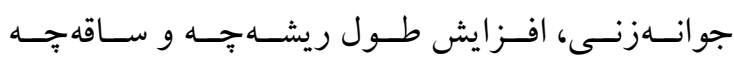

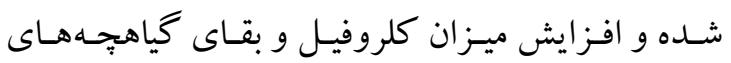

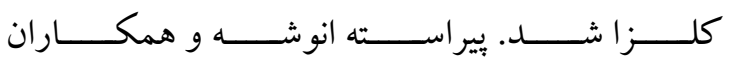
بـا ارزيـابى تـأثير (Pirasteh-Anosheh et al., 2014b) بيش تيمار بذر با غلظت هاى متفاوت كلرمكوات كلرايد بر جوانهزنى بذر، رشد و برخى ويز گیى هاى بيوشـيميايى شش كياه زراعى كندم، جو، ذرت، آفتابكردان، كلزاو و

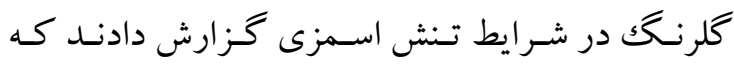
غلظت بهينه از كلرمكوات كلرايد بخش قابـلتوجهى از اثرات منفى تنش بر جوانه زنى بذر، رشد كياه، محتـواى يسرولين آزاد و شــاخص كلروفيـل را تعـديل كـرد. در شرايط تنش شورى متوسط، بيش تيمـار بـا كلرمكـوات كلرايد تأثير مثبت بيشترى داشت. افزايش غلظت بـيش تيمار با كلرمكوات كلرايد (از Y بـه F كَرم مـاده مـؤثره در ليتر) با افزايش تأثير مثبت آن همر اه بود، با ايسن حسال تفاوت عمدهاى بين بِاسخ گِياهان زراعى به يـيش تيمـار

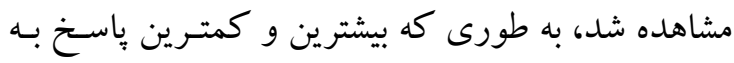
ترتيـب مربسوط بـه كلـزاو آفتـابكر دان بـود. هاشـمى و همكاران (Hashemi et al., 2012) نيز گز ارش دادند كـه بيش تيمار سايكوسل باعث بهبـود جوانسهزنسى و افـزايش رشد گياهجه كلرنَك در شرايط تنش اسـمزى كرديـد، كه در تيمارهاى بدون تنش و تسنش ملايسم، غلظت ه/ ه كرم در ليتر و در تنش هاى متوسط غلظـت ك/ه كرم در ليتر مناسبترين تيمارها بودند. علاوه بر كياهان زراعى، گياهان شـورزى كـه داراى تحمل بالايى به شورى نيز هستند، نسبت بـه يسيش تيمـار

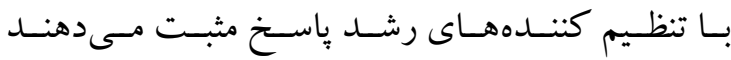


مس يابــ. مـورى و همكـاران (Moori et al., 2012) نيـز

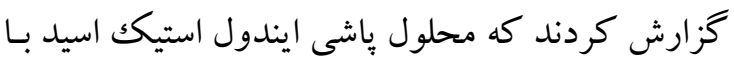

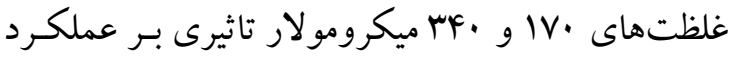

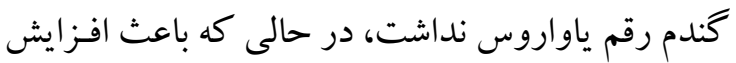

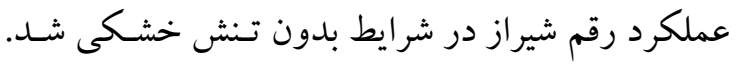

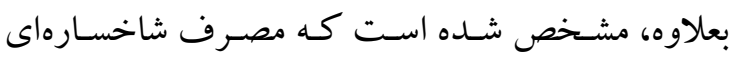

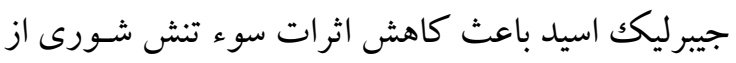

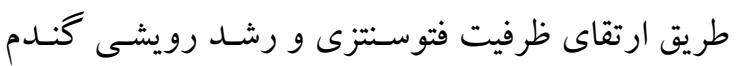
مىشود (Ashraf et al., 2002).

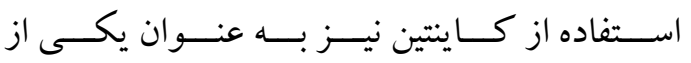

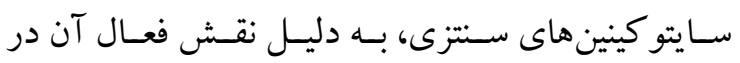

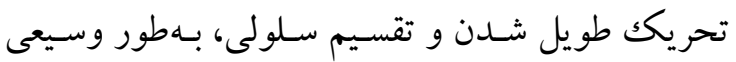

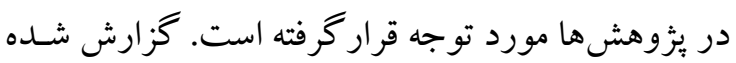

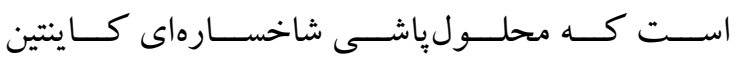
روى بوتههاى گندم مى تواند اثرات زيـان آور شـورى

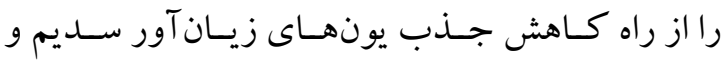

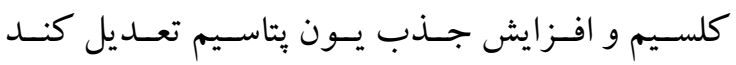

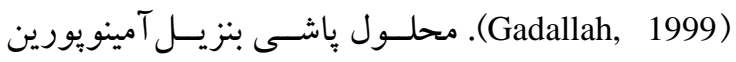

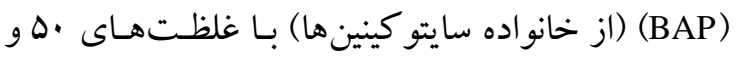

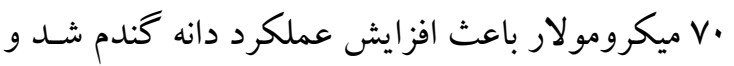

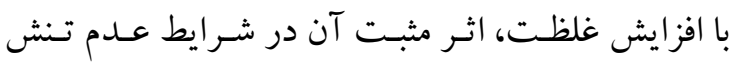
بيشتر شد (Moori et al., 2012).

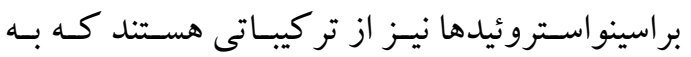
منظور افزايش تحمل به شورى در كياهان زراعى مـورد

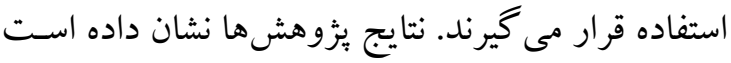

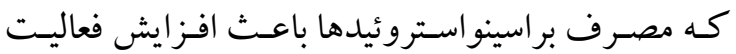

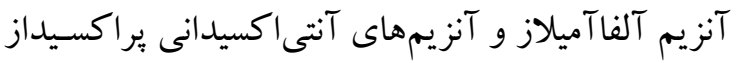

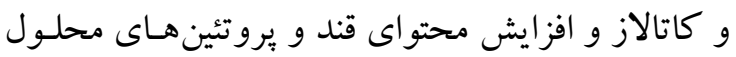
در بذرهاى در حال جوانهزنى در شرايط شور مى شـوند.

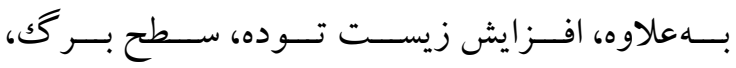
ســرعت فتوسـنتز، كــارايى فتوسيسـتم دو و افـزايش

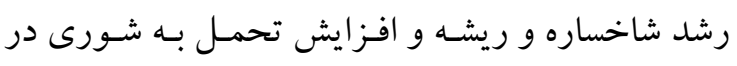

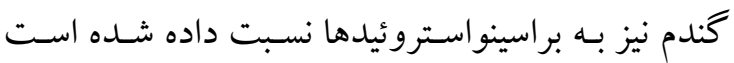

.(Shahbaz and Ashraf, 2007; Shahbaz et al., 2008)
كَزارش شــده اسـت. در همسين ارتبـاط اقبـال و اشـرف

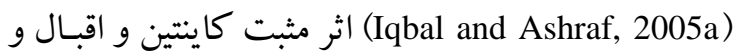
اشرف (Iqbal and Ashraf, 2010) اثر مثبت سه يلى آمين

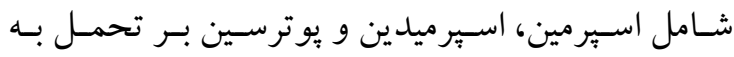
شورى بوتهاى كندم را گز ارش دادند.

\section{محلول ياشى تنظيم كنندههاى رشد}

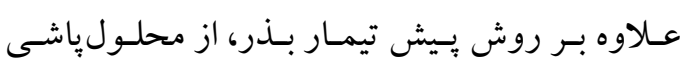

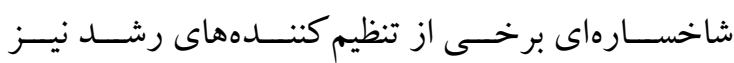

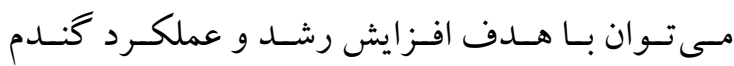

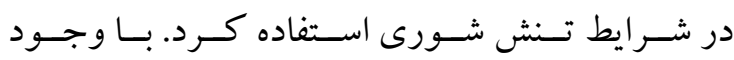
تفــاوتهـاى قابـل توجـهـ در ســازو كار تــاثير تنظـيم

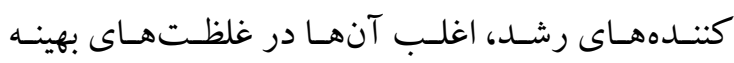
موجب رفع آسيب اكسايشى در شرايط تنش مسى رهوند.

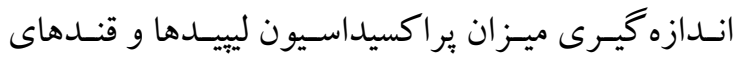

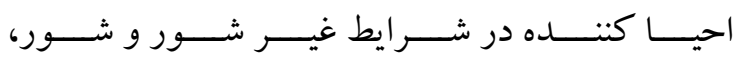

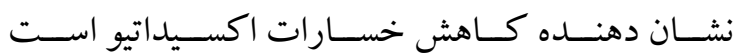
(Pirasteh-Anosheh and Emam, 2018b)

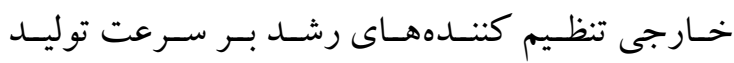

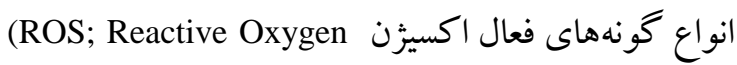
در شـرايط شـور تاثير گـــذار اسـت و فعاليـتـ آنـزيمهـاى آنتسى اكسـيدانى مانــــ كاتـالاز، براكسـيداز

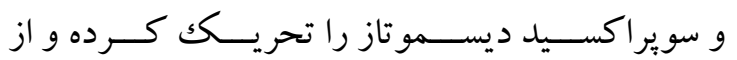

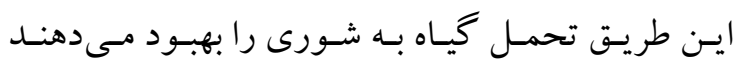

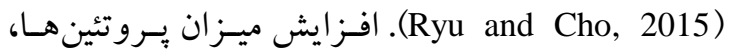

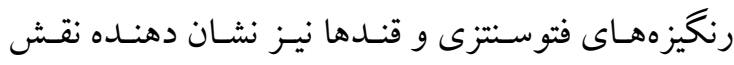

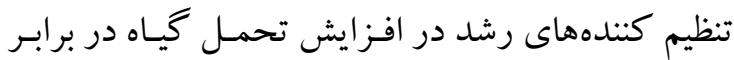
تسنش شـورى مسىباشـند (Sade et al., 2017). مهم تـرين ساز و كارهاى تاثير هريكك از تنظيم كنندههاى رشـــ در

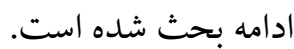
در محلول ياشى تنظيم كنندهاى رشد، زمان مناسب

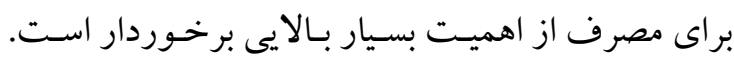

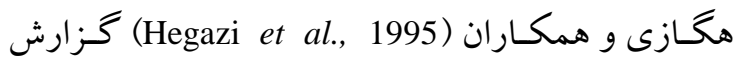

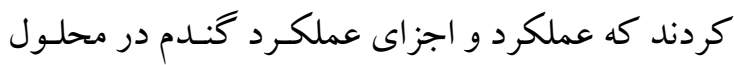
ياشى با ايندول اسـتيك اسـيد در شـرايط شـور افزايش 
بتاسيم و كلر نيز اثر معنىدارى داشـتند. در دو آزمـايش

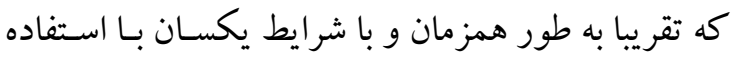

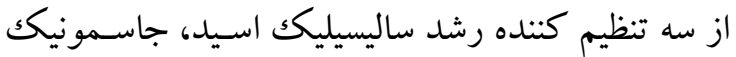

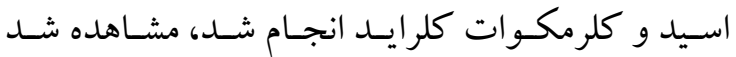

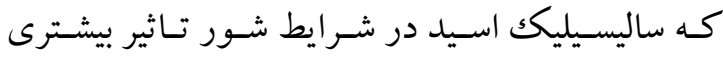

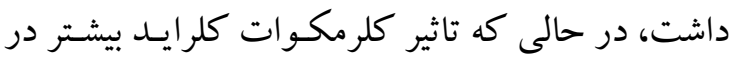

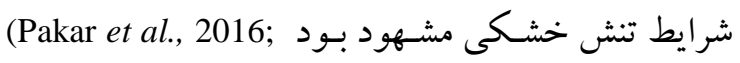
(Vahabi et al., 2016) مثبت و معنىدارى تحت تاثير مصرف ساليسيليكك اسـيد قـــرار كرفـت (Pirasteh-Anosheh et al., 2018). كلرمكوات كلرايــ از يـر مصـرف تـرين كند كنـــدهاى

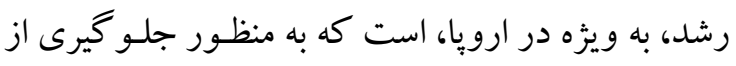

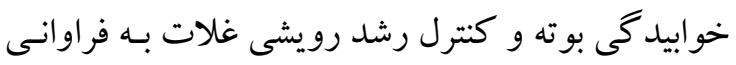

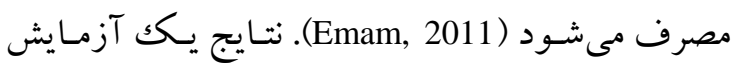

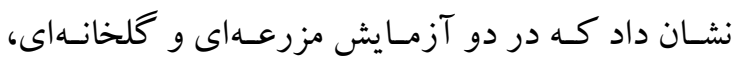

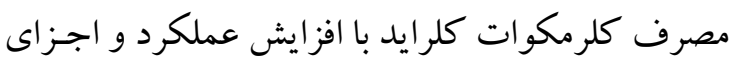

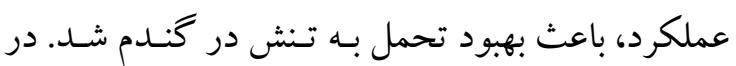

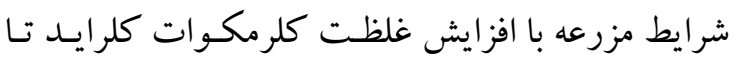

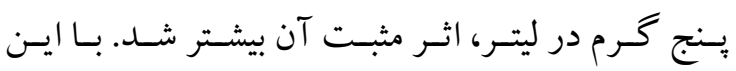

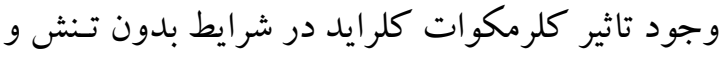
تـنش ملايسم بـارزتر بـود (Rokhafrooz et al., 2016).

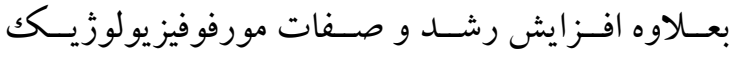
(Pirasteh-Anosheh and Emam, 2012a) اجـزاى عملكـــ (Pirasteh-Anosheh and Emam, اد 2012b) ، محتواى برولين آزاد، بـروتئينهـاى محلـول و

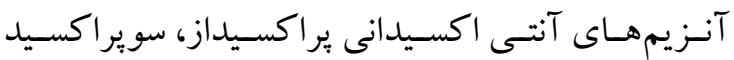
ديسمو تاز و كاتـالاز (Pirasteh-Anosheh et al., 2012) بـا مصـرف كلرمكـوات كلرايسـ در گنسـدم در شـرايط

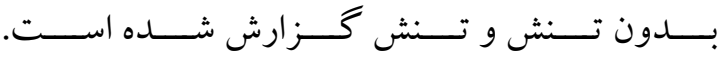

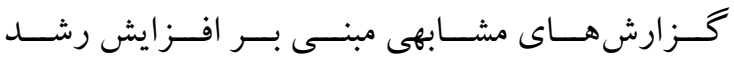
(Bahrami et al., 2014a) (Bahrami et al., 2014b; Pakar et al., 2016) جـو و كلـزا (Emadi and Pirasteh-Anosheh, 2019) در

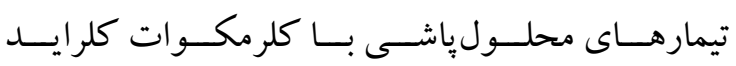

ساليسيليككاسـيد يكى ديخــر از هورمونهـاى مهـم

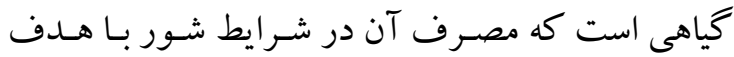
بهبود عملكرد، در آزمايشهاى زيادى مورد توجه قرار كرفته است. محلولياشى شاخسـارهاى ساليسيليككاسـيد

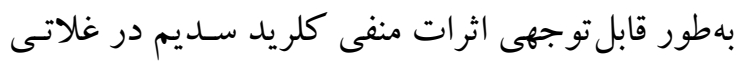

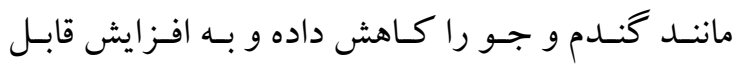

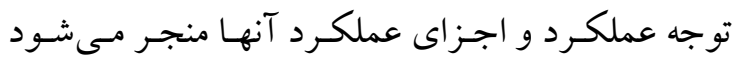
(Ashraf et al., 2010; Hayat et al., 2010; PirastehAnosheh et al., 2014a; Pirasteh-Anosheh et al., 2016c; Ranjbar and Pirasteh-Anosheh, 2017) آزمايشهايى كه در مورد محلولياشى بوتـهاى گنـدم با ساليسيليككاسيد در شر ايط شورى انجام شـده، دلايـل

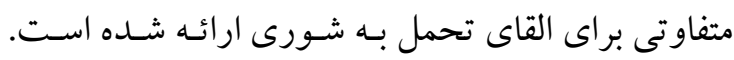

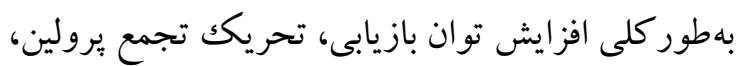

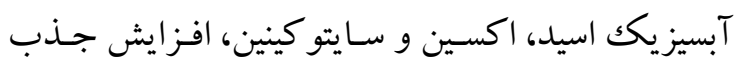
و انتقال بتاسيم و كلسيم، كاهش جـذب و انتقـال سـديم

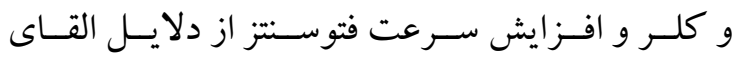

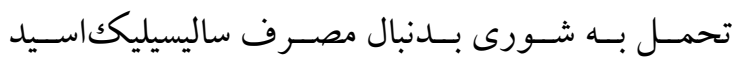
كزارش شدهاند Shakirova, 2007; Pirasteh-Anosheh et al., 2014c; Pirasteh-Anosheh and Emam, 2017; Pirasteh-Anosheh et al., 2017)

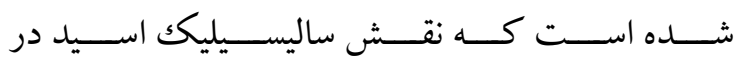
كـاهش خسـارت اكسـيداتيو ايجـاد شـده در اثر تسنش

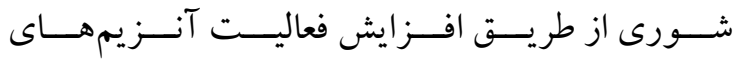

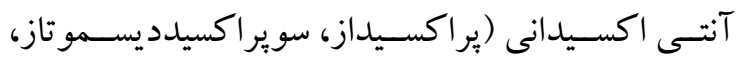

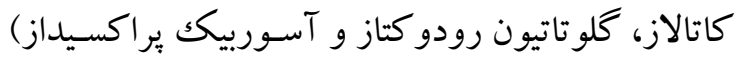

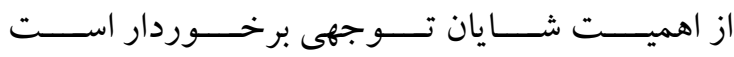
(Pirasteh-Anosheh and Emam, 2018b) و همكــاران (Pirasteh-Anosheh et al., 2016c) بــا اندازه گيرى غلظت يونهاى سديم، يتاسيم، كلر، كلسيم

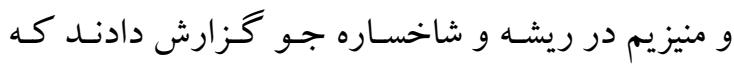
تحمل به شورى القاشده توسط ساليسيليكك اسـيد بيشتر

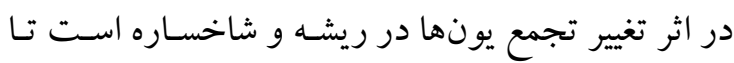

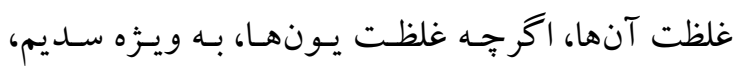




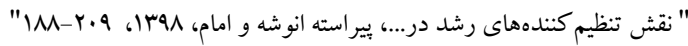

ATPase مهـدوى (Mahdavi, 2014) نيـز كـزارش داد كـه نتـايج بوششدار كردن و حبهدار كردن بذر با جيبرليككاسـيد،

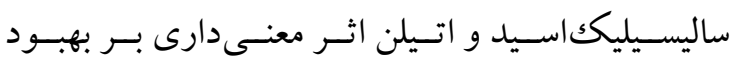

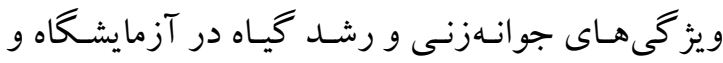
كلخانه داشت. بهطور كلى بـــرهاى بوشـش دار شـــه بـا

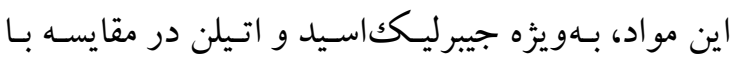
بــرهاى حبـهدار شـده، مناسـبـتر بـود. نتـايج آزمـايش ديخـرى (Suo et al., 2017) نشـان داد كـه يوشـشدار كردن بذر ذرت شيرين با تنظيم كنندهــاى رشــ 6-BA

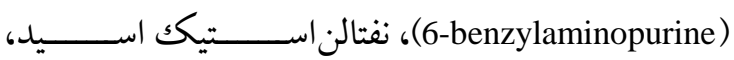
براسينوليد و جيرليككاسيد باعـث بهبـود قـدرت رويسش (ويخور) و جوانه زنسى بـذر و ظرفيـت آنتى اكسـيدانى

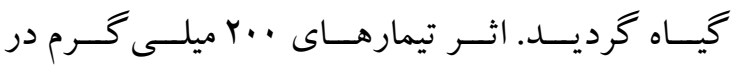
ليتر جيرليكاسيد و ·ب و ·• ميلى كرم 6-BA بيشتر بـود.

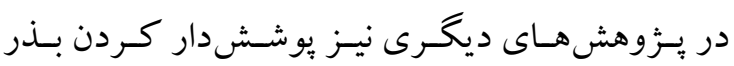

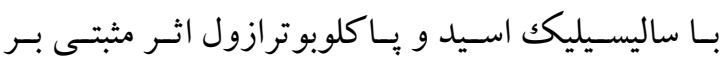

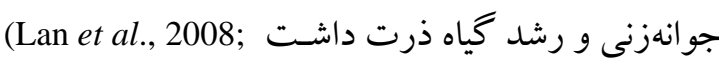
Wang et al., 2010; Zhu et al., 2013) بوشش شدار كردن بذر با مو اد آلى يا معسدنى (بـه ويـزّه در كياهان مرتعى) بهخوبى مورد بررسى قرار گرفتـه، لـيكن استفاده از تنظيم كنندهاى رشد براى بوشش دار كردن بذر بسيار كمتر مورد توجه قرار كرفته است. بهبود توان بازيابى كياه با استفاده از تنظيم كنندههاى رشد يكى از رهيافتـهـاى مناسـب در استفاده از تنظيم كنندهاى رشد كه كمتر مورد توجه قرار كرفتـه اسـت، تقويت توان بازيابى گياهان در شرايط تنش است. تـوان بازيابى بالا در شرايط تنش شورى مىتواند به بقاى گياه

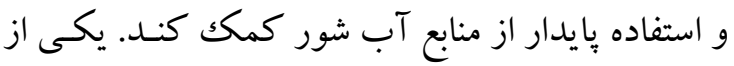
راهكارهـاى مــديريت آب شـور در مزرعـه، اسـتفاده دورواى از آب شــرين و شـور اسـت. در ايسن شـرايط كياهى كه توان ذاتا بازيابى بـالا داشـته و يـا بـا مصـرف

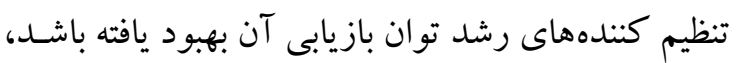
بهتر مى تواند زنده مانده و رشد كند. بعلاوه در شـرايطى
وجسود دارد. گَز ارش شـده اسـت كـه اكرجهـه مصـرف

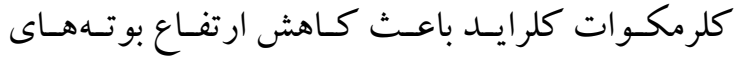
جــو در مراحسل يـــش از كلــدهى شــد، ولـى ارتفــاع

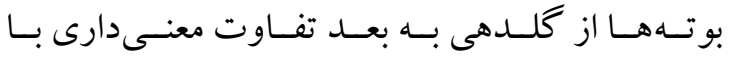

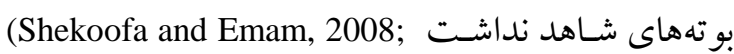
(Bahrami et al., 2014a) آبسـتنى تـا كلـدهى بـه افـزايش تجمـع بــش سـازهاى جيبرلين در انتهاى دوره ينجهزنى نسبت داده شده است.

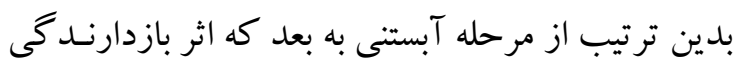
كلرمكوات كلرايد كـاهش مسىيابـد، سـنتز جيبـرلين بـا استفاده از مقدار زيادى بـيشسـاز كـه بلافاصـله يـس از مصرف كلرمكوات كلرايد تجمع مىيابد، از سر گرفتـه شده و همين موضوع باعث طويل شـدن سـريع سـاقه در (Rajala and Peltonen-Sainio, ايسن مرحله مسى گـردد .2001; Akinrinde, 2006)

يوششدار كردن بذر با تنظيم كنندهاى رشد

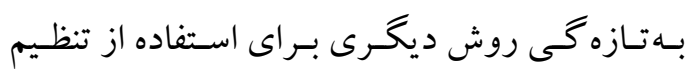
كنندههاى رشد ابداع شده اسـت. ايسن روش كـه نسـبت به روش هاى بيشين (ييش تيمار، محلولياشى و اسـتفاده در محيط كشت) جديدتر محسوب مىشود، بوشـش بـ كردن بذر با تنظيم كنتـدهــاى رشـد اسـت. بوشـش دار كردن بذر، با اهداف مختلفى مانـــد افز ايش سـرعت و

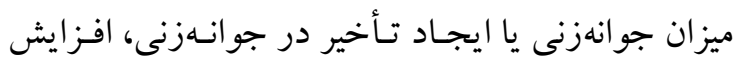
سـرعت و تـوان اسـتقرار كياهجـهـ، جلـو گيرى از زيـان آفات و بيمارىها يا خورده شدن بذر توسط حشـرات و جوند كان، حفظ رطوبت در اطـراف بـذر بـا اسـتفاده از مواد جاذب رطوبت، افزايش عملكرد و بهبود تحمل بـه تنش انجام مى گيرد (Mahdavi, 2014). نتايج يـك يُخروهش (Dong et al., 2019) نشـان داد كه بوششدار كردن بذر بادام زمينى با ساليسيليككاسـيد بهورت توليد ذرات كندرها (Slow release particles) باعث افزايش كميت و كيفيت محصول شـد. ايسن روش مصرف باعـث افـزايش فعاليـت آنـزيمهــاى مختلـف از

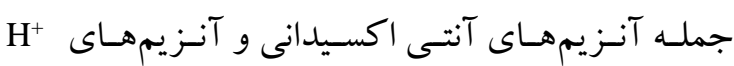


بازيابى شد؛ ولى با تشديد قلياييت، توان بازيابى مشاهده

جنبههاى كاربردى استفاده از تنظيم كنندههاى رشد

غلظت بهينه

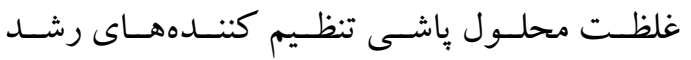

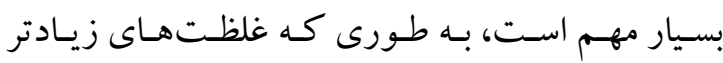

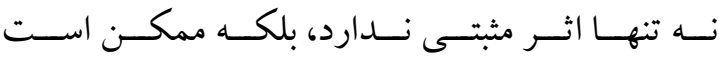

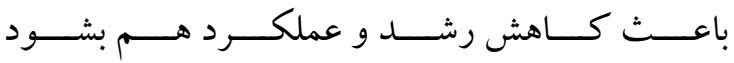

(Pirasteh-Anosheh and Emam, 2018a)

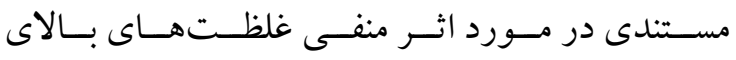

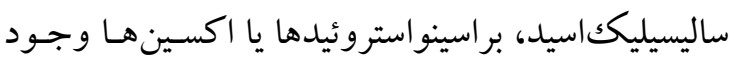

دارد (Ashraf et al., 2010; Hayat et al., 2010.

ساليسيليككاسيد و اكسين در غلظـتهـاى بـالا خاصيت

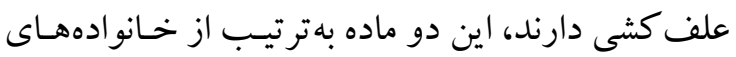

بنزويك اسيد و فنو كسى اسـيكك اسـيدها هستـند كـه از

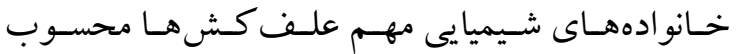

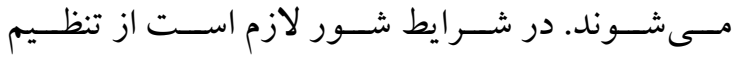

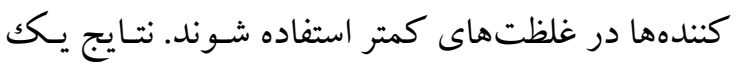

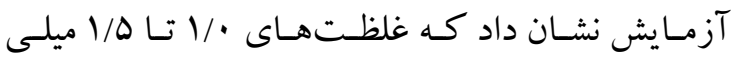

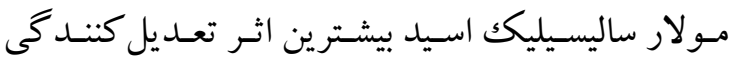
را داشته درحالى كـه غلظت دو ميلـىمـولار در شـرايط

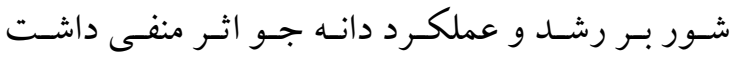
Pirasteh-Anosheh et al., 2015)

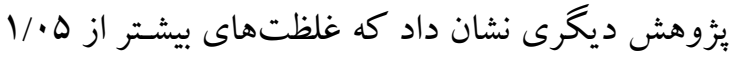

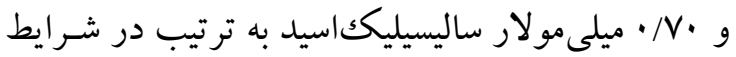
غيرشـور و شـور بـر عملكــــد جـو اثـر منفسى داشـتند

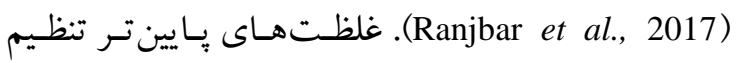

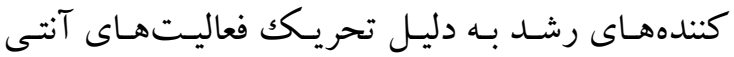

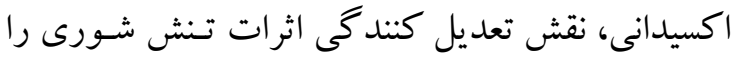

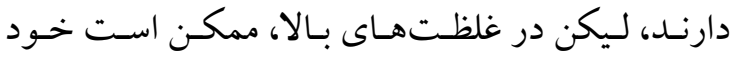

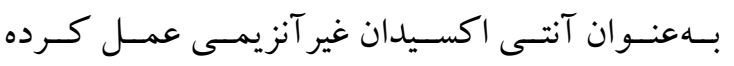

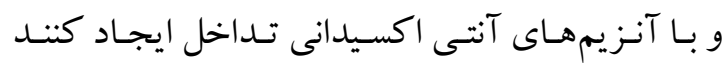
(Ashraf et al., 2010; Hayat et al., 2010; PirastehAnosheh et al., 2016a)
كه از آب مازاد براى توليـد محصـول اسـتفاده مسىشـود

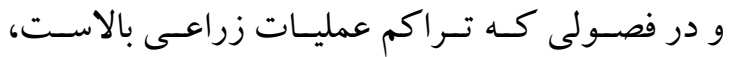
به دليل كاهش حجم آب مصرفى براى هر گياه، شورى

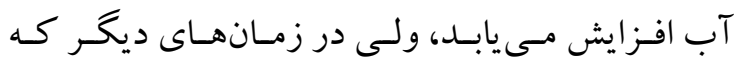
آب شيرين در دسترس مى باشد، تـوان بازيسابى كياهـان

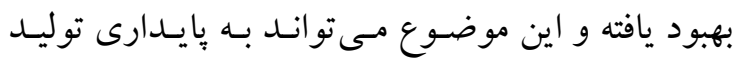

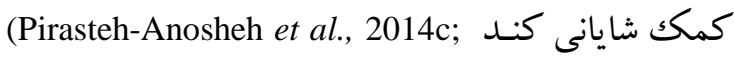
.Delaviz et al., 2016; Hashemi et al., 2018b)

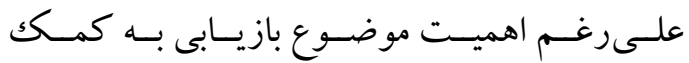

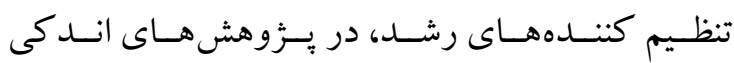
به آن برداختـه شـده اسـت. بير استهـه انوشـه و همكـاران

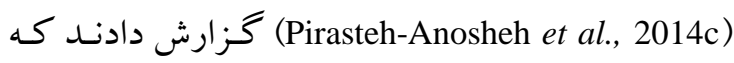
بازيابى گياه با محلول ياشى ساليسيليكك اسيد باعث بهبود

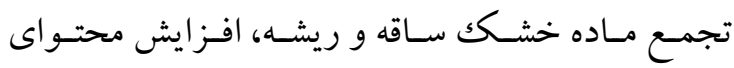

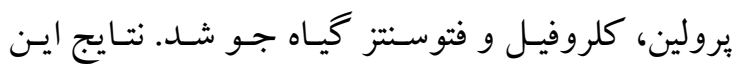

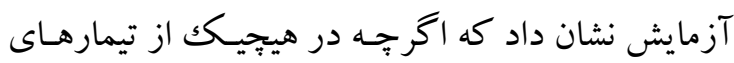

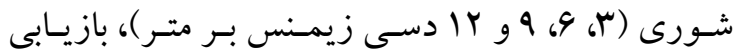

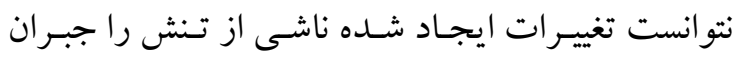

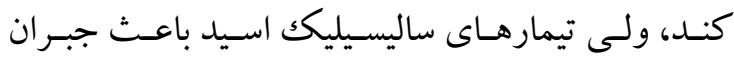
بخش زيادى از اين تغييرات منفى كرديد. هاشـمى و همكـاران (Hashemi et al., 2018b) بـا مقايسه اثر محلول باشى و ييش تيمـار ساليسيليك اسـيد

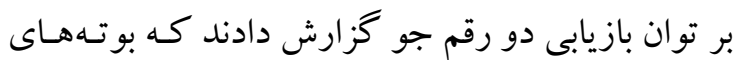

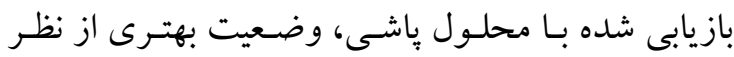

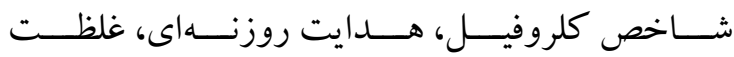

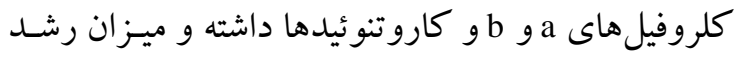

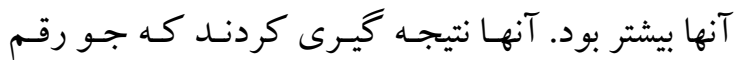
افضل نسبت به رقم ريحان توان بازيابى بيشترى داشـته و

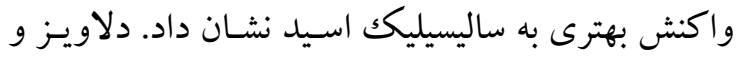

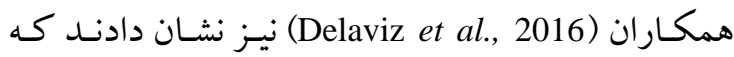
بـذرهاى بـيش تيمـار شـده (هيـدروبر ايمينگك) اسـيرس

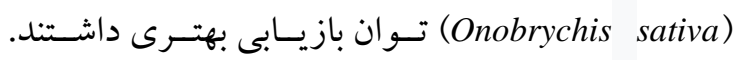
يبش تيمار بذرهاى با غلاف و بدون غلاف به ترتيـب تـا

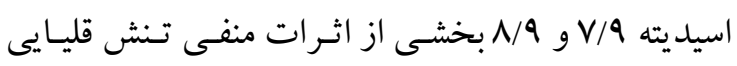




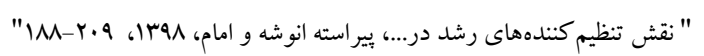

جدول r- دامنه غلظت هاى مورد استفاده براى تنظيم كنندهاى رشد گياهى

Table 2. Ranges of application concentration of plant growth regulators

\begin{tabular}{|c|c|c|c|c|c|}
\hline \multicolumn{5}{|c|}{ دامنه غلظت } & دامنه غلظت \\
\hline PGR & تنظيم كننده رشد & Concentration range $(\mu \mathrm{M})$ & PGR & ت تنظيم كنده رشد & Concentration range $(\mu \mathrm{M})$ \\
\hline Abscisic acid & آبسيزيكك اسيد & $1300-2300$ & Indole acetic acid & ايندول استيكك اسيد & $150-300$ \\
\hline Brassinosteroids & براسينواستروئيد & $0.02-0.08$ & Indole butyric acid & ايندول بوتيريكك اسيد & $150-300$ \\
\hline Salicylic acid & ساليسيليك اسيد & $1000-2000$ & Naphthalene acetic acid & نفتالن استيك اسيد & $150-300$ \\
\hline Chlormequat chloride & كلرمكوات كلرايد & $15000-25000$ & Phenyl acetic acid & فنيل استيك اسيد & $200-350$ \\
\hline Jasmonic acid & جاسمونيك اسيد & $100-500$ & Kinetin & كاينتين & $50-500$ \\
\hline Nitric oxide & نيتريك اكسايد & $100-300$ & Zeatin & زآتين & $50-250$ \\
\hline Strigolactones & استريو گالاكتون & $1-10$ & Benzyl aminopurine & بنزيل آمينويورين & $50-150$ \\
\hline Triacontanol & ترياكونتانول & $10-20$ & Gibberellic acid & جيبرليك اسيد & $1-3$ \\
\hline & & & Ascorbic acid & آسكو ربيك اسيد & $50-500$ \\
\hline
\end{tabular}

The presented numbers in table are the range of PGRs concentrations that showed positive effects in different experiments and are not necessarily the optimum concentrations 


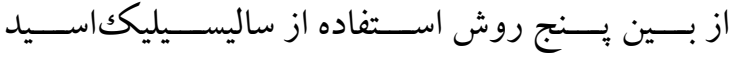

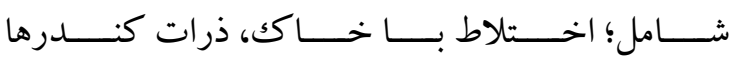
(slow release particles) آبيارى و محلولياشى روى گياه بادام زمينى، استفاده از روش ذرات كندرها، باعث افزايش ويز خى هـاى رشـد، عملكرد و كيفيت محصول شد. بعلاوه ساليسيليككاسـيد باعـث افـزايش فعاليـت آنـزيمهــاى $\mathrm{Fe}^{3+} \mathrm{H}^{3+}$ ATPase Chelate Reductase اسيديته خاكك شد. فعاليـت آنزيمهـاى آنتى اكسـيدانى سوير اكسيد ديسموتاز، يراكسيداز و كاتـالاز نيـز در اثر مصرف ساليسيليكاسيد افزايش يافتند. اين يزٔوهشخران

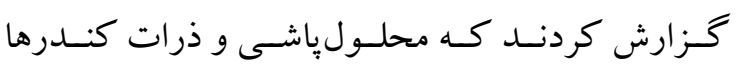
بيشترين كارايى را داشتند. رنجبـر و همكــاران (Ranjbar et al., 2017) نيـز

كز ارش كردند كه بهترين زمان مصرف تنظيم كنــدهـا در جو در مرحلـه برجستخى دو كانـه اسـت و تـا دوبـار محلول ياشى، اثرات مفيدى دارد، ولى افزايش دفعات

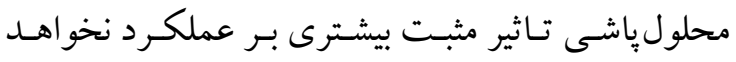
داشت. به نظر مىرسد كه تاخير در محلولياشى تنظيم كنندهاى رشد با كاهش اثرات آن همـراه باشـد و ايسن موضوع ممكن است مربوط به مرحله بحر انى تحمـل بـه

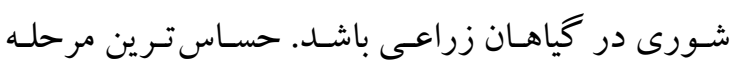
رشدى كياهان زراعى به شورى، مرحله استقرار كياهجه است و اكر كياهى اين مرحله را با موفقيت سيرى كنـد، تحمل به شـورى آن در مراحل بعـلى افـزايش يافتـه و

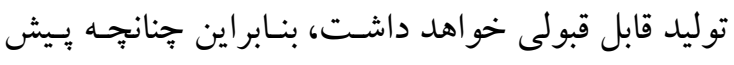
تيمار بذر با تنظيم كنندههاى رشد بتواند به اسـتقرار بهتـر

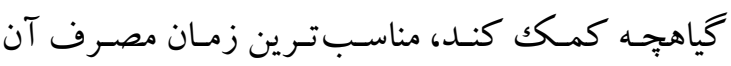
(Hayat et al., 2010; Hashemi et al., 2012; خو اهل بود 2015; 2018a; Pirasteh-Anosheh et al., 2014a) مجموع، به نظر مىرسد كه بهترين زمان تيمـار بـا تنظيم

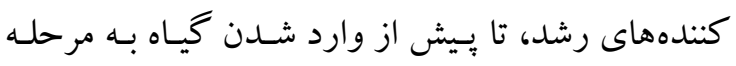
زايشى، با دو بـار مصسرف بـه فاصـله ها- • ا روز باشـد. البته اين توصيه كلى مربـوط بـهـ كياهـان زراعى بـوده و

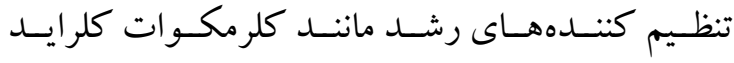
،(Bahrami et al., 2014a; Rokhafrooz et al., 2016) (Pakar et al., 2014; Vahabi et al., جاسمونيك اسـيد (Moori et al., 2012) نيـز ( 2016) اثرات متفاوتى دارند، بنابراين براى هر تنظيم كننده بايــ غلظت بهينه آن مشخص شده و مورد استفاده قرار كيرد.

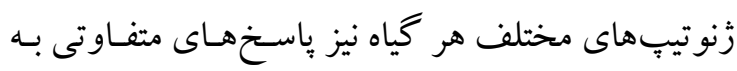
تنظيم كنندهاى رشـد دارنـد (Bahrami et al., 2014b).

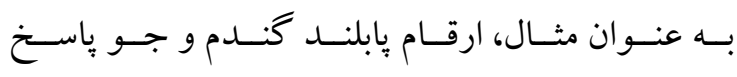
بهتــرى بـه تنظـيم كنتــدهــاى كند كنتـده رشـــ نشـان (Pirasteh-Anosheh and Emam, 2012a; دادنــــ Bahrami et al., 2014a)

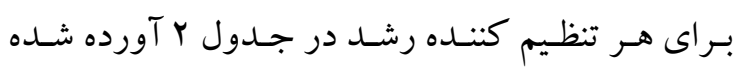
است. هر جند اين مقادير غلظت بهينه قطعى نبوده و لازم

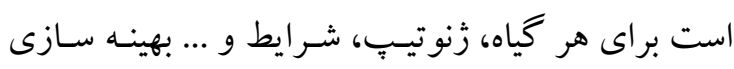
لازم انجام شود.

روش و زمان مصرف

تنظيم كنندهاى رشد به روشهـاى مختلفى بـه كـار برده مىشوند. بيش تيمار بذر با هدف بهبود جوانهزنى،

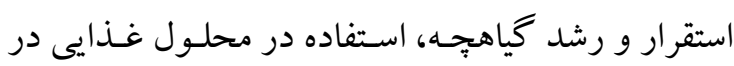
كشـت هيـدرويونيكك و محلـولياشـى شاخسـارهاى، بـا هدف بهبود رشد و عملكرد گياهـان زراعسى در شـرايط هيط شـورى از روشهـاى مصـرف تنظيم كنتـدهــاى رشـد هستند. اشـرف و همككاران (Ashraf et al., 2010) در مورد روش استفاده از تنظيم كنندههاى رشد براى بهبـود

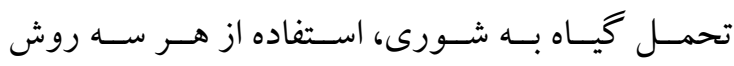
محلولياشى، بيش تيمار بذر و محلول غـذايى در محيط ريشه را امكان يذّير دانستهاند. به نظر ايشان، يـيش تيمـار

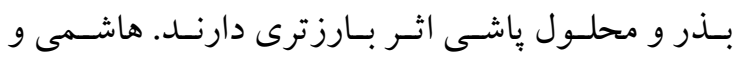
همكــاران (Hashemi et al., 2018a; 2018b نيـز بــا ارزيابى زمان محلول ياشى بيان داشتند كه بيش تيمـار و

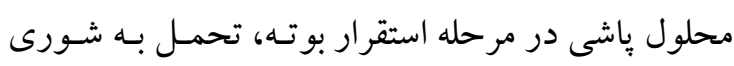
بيشترى را در كياه جو به دنبال دارد. بر اساس نتايج يـك آزمـايش (Dong et al., 2019)، 


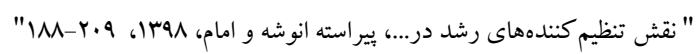

$$
\text { ارزيام ميى اقتصادى. }
$$

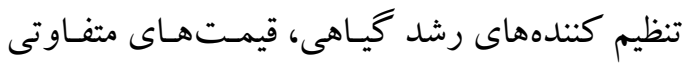

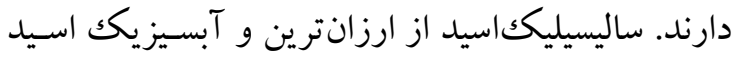

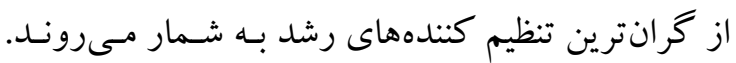

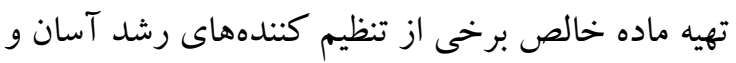

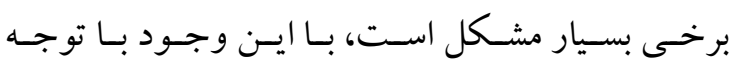

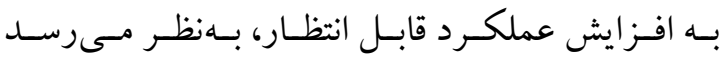

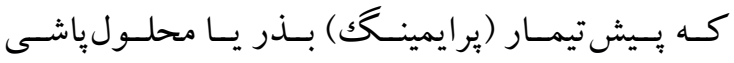

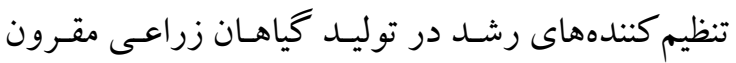

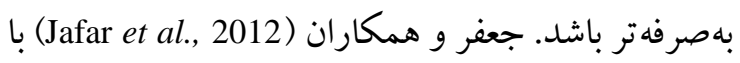

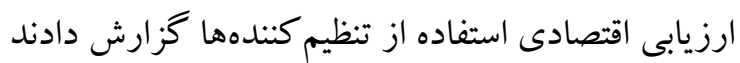
كـه نسـبت سـود بـه هزينـه در تيمارهـاى شـاهد (بـدون

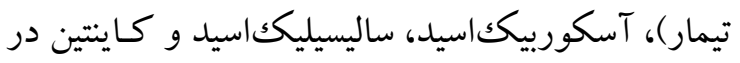

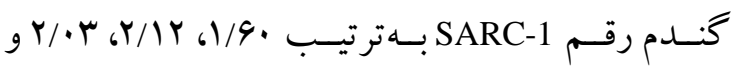

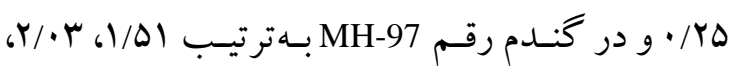

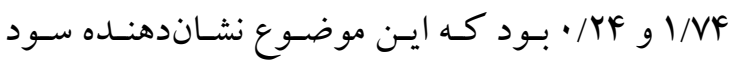

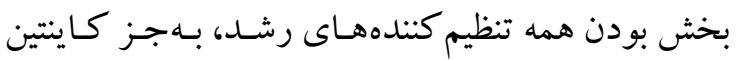

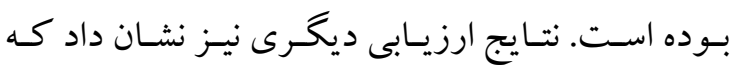

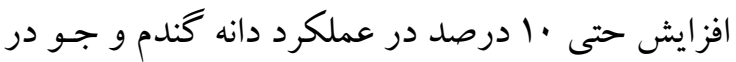
اثر بر ايمينگك و محلول ياشى ساليسليككاسيد، سود قابـل

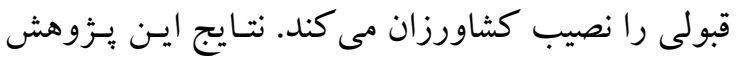

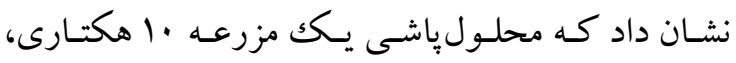

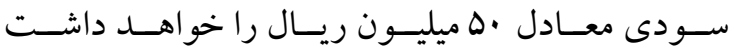

.(Ranjbar and Pirasteh-Anosheh, 2017)

\section{نتيجه كيرى}

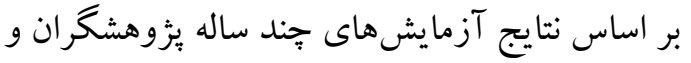
بررسى هاى انجام شده ميدانى، اثر مثبت تنظيم كنندهای

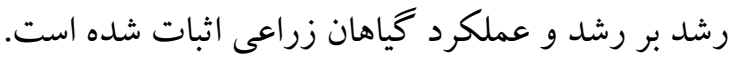

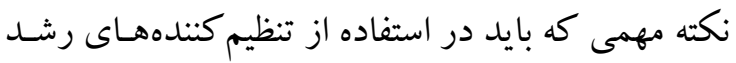

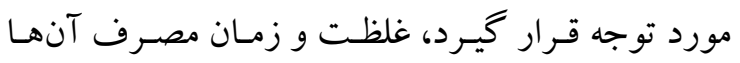

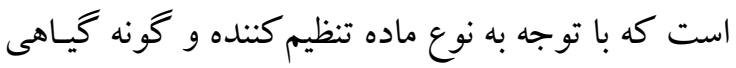
بايد مشـخص شـود. مصـرف فراتـر از غلظت بهينه، در
ممكن است براى همه گياهان صادق نباشد. روش يِشتيمار (يرايمينك) بذر

در روش يسيشتيمـار، بـــرها در محلـولهــاى بــا

غلظت مناسب (براى هر تنظيم كننده رشد) به مدت 1 تا

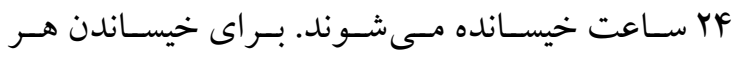

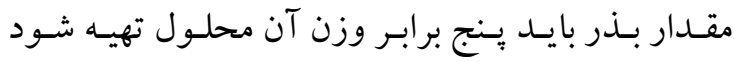

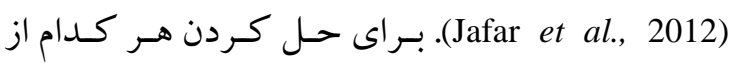
تنظيم كنتسدهــاى رشـد، روش خاصسى وجــود دارد.

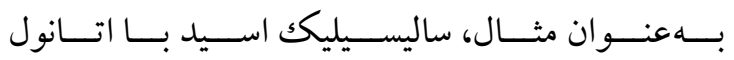
و و يــا (Pirasteh-Anosheh et al., 2014a) كلرمكوات كلر ايد در آب گرم به راحتى حل مىشـوند (Rajala and Peltonen-Sainio, 2001) بذرها در معـرض هـوا در سـايه قـرار داده مسىشـوند تـا

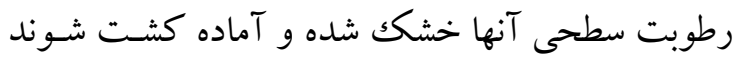
.(Ranjbar and Pirasteh-Anosheh, 2017)

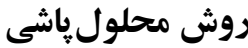

در روش محلول ياشى بِ از تهيه محلول بـا غلظـت مناسب براى هر كدام از تنظيم كنندهاى رشد، محلـول

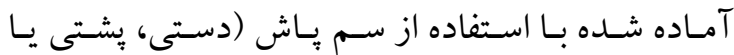

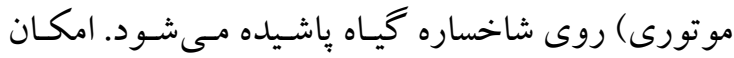

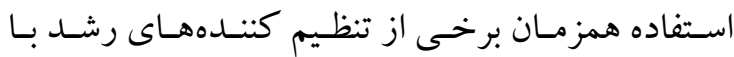
علف كشها نيز وجـود دارد، ليكن بهتر اسـت فاصـله زمـانى مناسـب بــن اسـتفاده از آنهـا رعايـت شـود Ranjbar and Pirasteh-Anosheh, 2017) محلول ياشى بايد دقت شود كه محلـول بـه طـور مــاوم هم زده شود تا ماده تنظيم كنـــده در تـه مخززن محلـول ياش رسوب نكنـد (Pirasteh-Anosheh et al., 2014a).

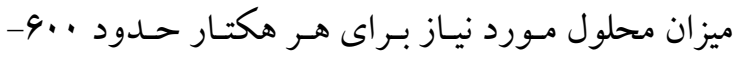

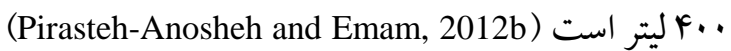
و محلول ياشى تا جايى ادامه مىيابد كه قطرات محلـول

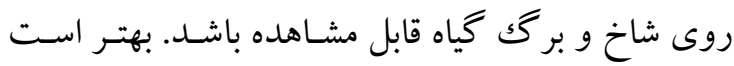

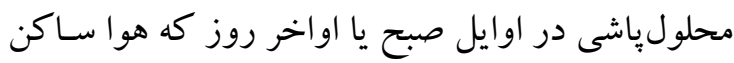
و شدت تابش خورشيد كمتر است انجام شود. اين كار با هدف جلو كيرى از تبخير و كاهش هـدررفت محلـول 


$$
\begin{aligned}
& \text { "نشريه علوم زراعى ايران"، جلد بيست و يكم، شماره "ا، إييز بوسا } \\
& \text { بهنظر مسىرســ كـه دسـتيابى بـه جنـين موفقيـتهـايى }
\end{aligned}
$$

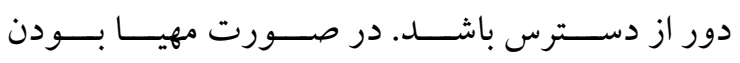

$$
\begin{aligned}
& \text { مورد برخى از تنظيم كنتـدههـا بـه طور قطع و در مـورد }
\end{aligned}
$$

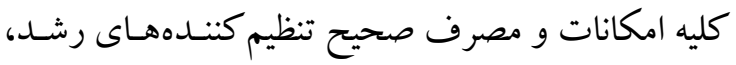

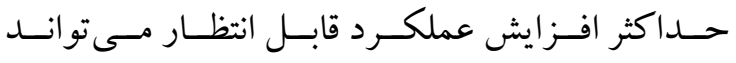

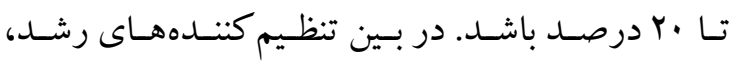

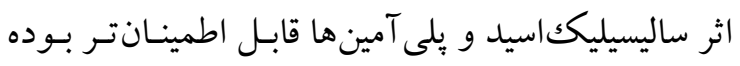

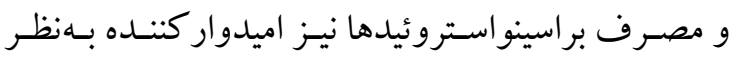

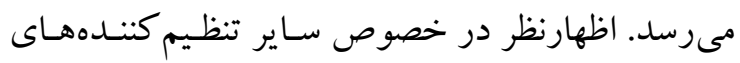

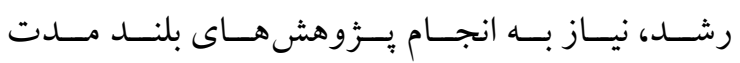

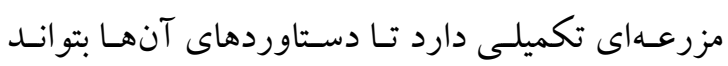

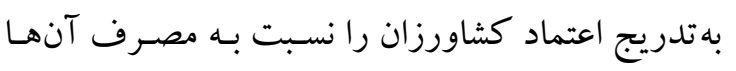

$$
\begin{aligned}
& \text { جلب كند. }
\end{aligned}
$$

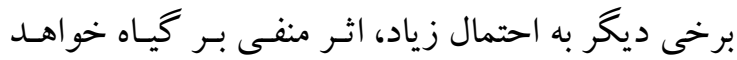

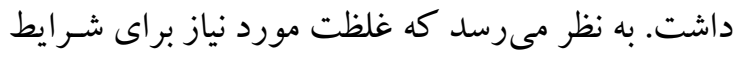

$$
\begin{aligned}
& \text { شور كمتر از شرايط غيرشور باشد. اين موضوع لهو احتمـالا }
\end{aligned}
$$

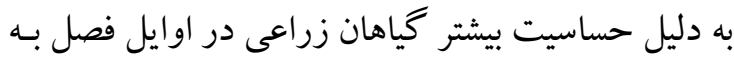

$$
\begin{aligned}
& \text { تنش شورى است. مصرف تنظيم كنندهاى رشــ در دو } \\
& \text { نوبت (اوايل فصل و بيش از شروع رشد زايشى) نيـز بـائ } \\
& \text { تأثير بيشترى همر اه است. }
\end{aligned}
$$

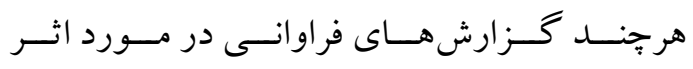

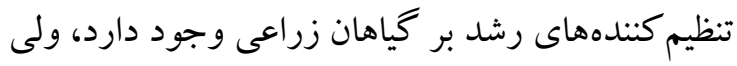

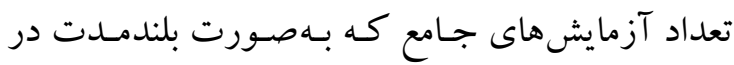

$$
\begin{aligned}
& \text { مقياس وسيع مزرعهاى روى اين موضسوع تمركز كـرده }
\end{aligned}
$$

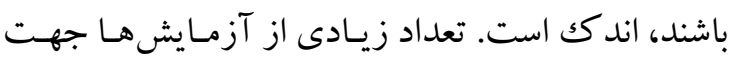

$$
\begin{aligned}
& \text { سياسگزارى } \\
& \text { بدينوسيله از آقـاى دكتـر مسعود اصففهانى سـردبير } \\
& \text { محترم نشريه علوم زراعى ايران و داوران محترم ناشناس دئ دئس }
\end{aligned}
$$

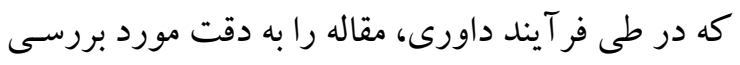

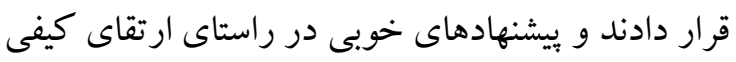

$$
\begin{aligned}
& \text { مقاله داشتند تقدير و تشكر مى گرد دد. }
\end{aligned}
$$

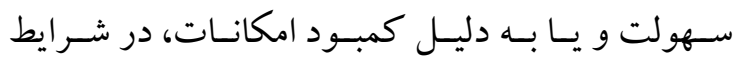

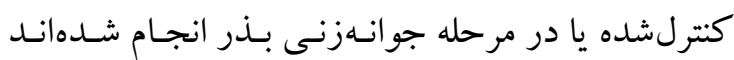

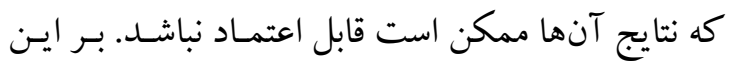

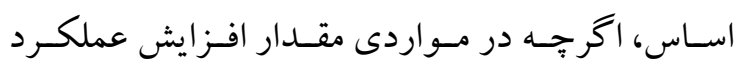

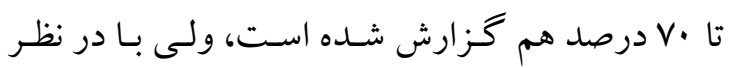

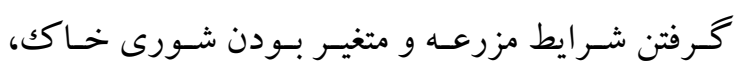

\section{References}

Adler, P. R. and G. E. Wilcox. 1987. Salt stress, mechanical stress, or chlormequat chloride effects on morphology and growth recovery of hydroponic tomato transplants. J. Amer. Soc. Hort. Sci. 112: 22-25.

Afzal, I., S. M. A. M. Basra, A. Farooq and A. Nawaz. 2006. Alleviation of salinity stress in spring wheat by hormonal priming with ABA, salicylic acid and ascorbic acid. Int. J. Agric. Biol. 8: 23-28.

Akinrinde, E. A. 2006. Growth regulator and nitrogen fertilization effects on performance and nitrogen use efficiency of tall and dwarf varieties of rice (Oryza sativa). Biotechnol. 5: 268-276.

Ashraf, M., F. Karim and E. Rasul. 2002. Interactive effects of gibberellic acid $\left(\mathrm{GA}_{3}\right)$ and salt stress on growth, ion accumulation and photosynthetic capacity of two spring wheat (Triticum aestivum L.) cultivars differing in salt tolerance. Plant Growth Regul. 36: 49-59.

Ashraf, M. and M. R. Foolad. 2005. Pre-sowing seed treatment. A shotgun approach to improve germination, plant growth and crop yield under saline and non-saline conditions. Adv. Agron. 88: 223-271.

Ashraf, M., N. A. Akram, R. N. Arteca and M. R. Foolad. 2010. The physiological, biochemical and molecular roles of brassinosteroids and salicylic acid in plant processes and salt tolerance. Crit. Rev. Plant Sci. 29: 162-190. 


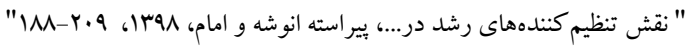

Bahrami, K, H. Pirasteh-Anosheh and Y. Emam. 2014a. Yield and growth parameters of barley cultivars as affected by foliar application of cycocel with different concentrations in Fars Province. Crop Physiol. J. 21 17-27. (In Persian with English abstract).

Bahrami, K, H. Pirasteh-Anosheh and Y. Emam. 2014b. Yield and yield components responses of barley cultivars to foliar application of cycocel. J. Crop Prod. Proces. 12: 27-36. (In Persian with English abstract).

Bari, R., and J. D. Jones. 2009. Role of plant hormones in plant defence responses. Plant Mol. Biol. 69(4): 473-488.

Bradford, K. J. 1986. Manipulation of seed water relations via osmotic priming to improve germination under stress conditions. Hort Sci. 21: 1105-1112.

Davies, P. J. 2013. Plant Hormones: Physiology, Biochemistry and Molecular Biology. Springer Science \& Business Media.

Delaviz. M., H. Sadeghi, H. Pirasteh-Anosheh and G. Ranjbar. 2016. Effect of seed pre-treatment methods on alkali stress tolerance of sainfoin and its recovery in germination and early growth. Iran. Seed Res. J. 3(1): 99-107.

Delledonne, M., Y. Xia, R. A. Dixon and C. Lamb. 1998. Nitric oxide functions as a signal in plant disease resistance. Nature. 394: 585-588.

Dong, Y., Y. Wan, F. Liu and Y. Zhuge. 2019. Effects of exogenous SA supplied with different approaches on growth, chlorophyll content and antioxidant enzymes of peanut growing on calcareous soil. J. Plant Nutr. 42(16): 1869-1883.

Emadi, A. R. and H. Pirasteh-Anosheh. 2019. The effect of chlormequat chloride foliar application and different levels of nitrogen fertilizer on yield and yield components of rapeseed (Brassica napus L.). Plant Ecophysiol. (Accepted). (In Persian with English abstract).

Emam, Y. 2011. Cereal Crop Production. Shiraz University Press. 190 pp. (In Persian).

Fariduddin, Q., T. A. Khan, M. Yusuf, S. T. Aafaqee and R. R. A. E. Khalil. 2018. Ameliorative role of salicylic acid and spermidine in the presence of excess salt in Lycopersicon esculentum. Photosyn. 56(3): 750-762.

Gadallah, M. A. A. 1999. Effects of kinetin on growth, grain yield and some mineral elements in wheat plants growing under excess salinity and oxygen deficiency. Plant Growth Regul. 27: 63-74.

Hashemi, S. E., H. Pirasteh-Anosheh and Y. Emam. 2012. Role of cycocel in modulation of drought stress on germination and early growth of safflower. The $1^{\text {st }}$ National Conference in Abiotic. Stress, 26-27 Oct., 2012 , Isfahan, Iran. (In Persian with English abstract).

Hashemi, S. E, Y. Emam and H. Pirasteh-Anosheh. 2015. The effect of time and type of salicylic acid application on growth trend, yield and yield components of barley (Hordeum vulgare L.) under salinity stress conditions. Crop Physiol. J. 24: 5-18. (In Persian with English abstract).

Hashemi S. E, Y. Emam and H. Pirasteh-Anosheh. 2018a. Ion content and antioxidant response of barley to different methods of salicylic acid application under salinity conditions. Plant Ecophysiol. 34: 1-11. (In Persian with English abstract). 


$$
\text { "نشريه علوم زراعى ايران"، جلد بيست و يكم، شماره ب، باييز اهوسا }
$$

Hashemi, S. E., H. Pirasteh-Anosheh and Y. Emam. 2018b. Recovery of negative effects of salt stress in two barley cultivars using salicylic acid. The $15^{\text {th }}$ International Iranian Crop Sci. Congress, 4-6 Sep., Karaj, Iran.

Hashemi, S. E., H. Pirasteh-Anosheh and Y. Emam. 2018c. Responses of germination, early growth and phenology in barley to salicylic acid and salinity. Cereal Res. 7: 579-590. (In Persian with English abstract).

Hayat, Q., S. Hayat, M. Irfan and A. Ahmad. 2010. Effect of exogenous salicylic acid under changing environment: a review. Environ. Exp. Bot. 68: 14-25.

Hegazi, A. M., F. M. El-Gaaly and N. M. N. El-Din. 1995. Effect of some growth regulators on yield and yield components of wheat grown under saline conditions. Ann. Agric. Sci. 33: 709-717.

Iqbal, M., and M. Ashraf. 2005a. Presowing seed treatment with cytokinins and its effect on growth, photosynthetic rate, ionic levels and yield of two wheat cultivars differing in salt tolerance. J Integ. Plant Biol. 47: 1315-1325.

Iqbal, M. and M. Ashraf. 2005b. Changes in growth, photosynthetic capacity and ionic relations in spring wheat (Triticum aestivum L.) due to pre-sowing seed treatment with polyamines. Plant Growth Regul. 46: 19-30.

Iqbal, M., and M. Ashraf. 2010. Changes in hormonal balance: a possible mechanism of pre-sowing chillinginduced salt tolerance in spring wheat. J. Agron. Crop Sci. 196: 440-454.

Jafar, M. Z., M. Farooq, M. A. Cheema, I. Afzal, S. M. A. Basra, M. A. Wahid, T. Aziz and M. Shahid. 2012. Improving the performance of wheat by seed priming under saline conditions. J Agron. Crop Sci. 198: 38-45.

Khan, M. A. and D. J. Weber. 1986. Factors influencing seed germination in Salicornia pacifica var. utahensis. Am. J. Bot. 73: 1163-1167.

Lan, X. and X. Wang. 2008. Effects of paclobutrazol seed-coating on seed germination and seedling growth in maize under drought stress. J. Maize Sci. 16(2): 94-96.

Mahdavi, H. 2014. Evalution of seed coating and pelleting with different chemicals and plant growth promoting rihzobacteria on germination of sugar beet (Beta vulgaris). M.Sc. Thesis, Shahed University, Tehran, Iran. (In Persian with English abstract).

Mata, C. G. and L. Lamattina. 2001. Nitric oxide induces stomatal closure and enhances the adaptive plant responses against drought stress. Plant. Physiol. 126: 1196-1204.

Moori, S., Y. Emam, H. Karimzadeh and H. Pirasteh-Anosheh. 2012. Effect of foliar application of auxin and cytokynin on yield and biochemical properties of Shiraz and Yavarous wheat cultivars under late season drought stress. 12 $2^{\text {th }}$ Iran. Crop Sci. Congress, 4-6 September, Karaj. Iran. (In Persian with English abstract).

Moradi, F. 2016. Plant growth regulators past, present and future. Res. Achiev. Field Hortic. 5(2): 71-95.

Nadjafi, F., M. Bannayan, L. Tabrizi and M. Rastgoo. 2006. Seed germination and dormancy breaking techniques for Ferula gummosa and Teucrium polium. J. Arid Environ. 64(3): 542-547.

Nasibi, F., K. Manoochehri Kalantari and M. Khodashenas. 2009. The effect of sodium nitroprusside (SNP) pretreatment on some biochemical parameters in tomato seedlings (Lycopersicun esculentum) under drought 


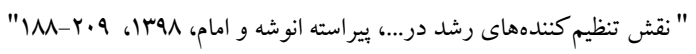

stress. J. Agric. Nat. Resour. Sci., 16: 1-14. (In Persian with English abstract).

Pakar, N., H. Pirasteh-Anosheh and Y. Emam. 2014. The effect of different concentrations of salicylic acid on barley qualitative and quantitative characteristics under salt stress conditions. J. Crop Prod. Proces. 14: $191-201$

Pakar, N., H. Pirasteh-Anosheh, Y. Emam and M. Pessarakli. 2016. Barley growth, yield, antioxidant enzymes and ion accumulation as affected by PGRs under salinity stress conditions. J. Plant Nutr. 39 (10): 1372-1379.

Peleg, Z., and E. Blumwald. 2011. Hormone balance and abiotic stress tolerance in crop plants. Curr. Opin. Plant Biol. 14(3): 290-295.

Pirasteh-Anosheh, H. and Y. Emam. 2010. Effect of plant growth regulators on total protein, proline content and antioxidant enzymes in two wheat cultivars under drought stress conditions. The National Proteomics Congress. 28-29 October, Shiraz University. Shiraz, Iran.

Pirasteh-Anosheh, H., H. Sadeghi and Y. Emam. 2011. Chemical priming with urea and $\mathrm{KNO}_{3}$ enhances maize hybrids (Zea mays L.) seed viability under abiotic stress. J. Crop Sci. Biotechnol., 14 (4): 289 - 295.

Pirasteh-Anosheh, H. and Y. Emam. 2012a. Manipulation of morpho-physiological traits in bread and durum wheat by using PGRs at different water regimes. J. Crop Prod. Proc., 5: 29-45. (In Persian with English abstract).

Pirasteh-Anosheh, H. and Y. Emam. 2012b. Yield and yield components responses of bread and durum wheat to PGRs under drought stress conditions in field and greenhouse. Environ. Str. Crop Sci. 5 (1): 1-18. (In Persian with English abstract).

Pirasteh-Anosheh, H., Y. Emam, M. Ashraf and M. Foolad. 2012. Exogenous application of salicylic acid and chlormequat chloride alleviates negative effects of drought stress in wheat. Adv. Stud. Biol., 11 (4): 501-520.

Pirasteh-Anosheh, H., Y. Emam and M. Pessarakli. 2013. Changes in endogenous hormonal status in corn (Zea mays L.) hybrids under drought stress. J. Plant Nutr. 36: 1695-1707.

Pirasteh-Anosheh, H., M. J. Rousta and Y. Emam. 2014a. Different methods of crops treatments with salicylic acid in salinity researches. Technical Bulletin. AREEO press, Tehran, Iran. (In Persian).

Pirasteh-Anosheh, H., Y. Emam and M. Ashraf. 2014b. Impact of cycocel on seed germination and growth in some commercial crops under osmotic stress conditions. Archiv. Agron. Soil Sci. 60(9): 1277-1289.

Pirasteh-Anosheh, H., G. Ranjbar, Y. Emam and M. Ashraf. 2014c. Salicylic acid-induced recovery ability in salt-stressed Hordeum vulgare plants. Turk. J. Bot. 38: 112-121.

Pirasteh-Anosheh, H., Y. Emam and A. R. Sepaskhah. 2015. Improving barley performance by proper foliar applied salicylic-acid under saline conditions. Int. J. Plant Prod. 9(3): 467-486.

Pirasteh-Anosheh, H., G. Ranjbar, H. Pakniyat and Y. Emam. 2016a. Physiological mechanisms of salt stress tolerance in plants; An overview. In: Azooz M. M. and P. Ahmad (Eds). Plant-Environment 


$$
\text { "نشريه علوم زراعى ايران"، جلد بيست و يكم، شماره با، باييز بهسا }
$$

Interaction: Responses and Approaches to Mitigate Stress. p. 141-160. John Wiley \& Sons, London, UK.

Pirasteh-Anosheh, H., Y. Emam and A. Khaliq. 2016b. Response of cereals to cycocel application: A review. Iran Agric. Res. 35(1): 1-12.

Pirasteh-Anosheh, H., Y. Emam, M. J. Rousta and M. Ashraf. 2016c. Salicylic acid induced salinity tolerance through manipulation of ion distribution rather than ion accumulation. J. Plant Growth Regul. 36: 227-239.

Pirasteh-Anosheh, H. and Y. Emam. 2017. Induced salinity tolerance and altered ion storage factor in Hordeum vulgare plants upon salicylic-acid priming. Iran Agric. Res. 36(1): 41-48.

Pirasteh-Anosheh, H., Y. Emam, M. J. Rousta and S. E. Hashemi. 2017. Effect of salicylic acid on biochemical attributes and grain yield of barley (Hordeum vulgare L. cv. Nosrat) under saline conditions. Iran. J. Crop Sci. 18(3): 232-244. (In Persian with English abstract).

Pirasteh-Anosheh, H. and Y. Emam. 2018a. Improved crop yield using plant growth regulators in saline conditions, theory or reality? The $2^{\text {nd }}$ National Conference on Salinity Stress in Plants and Developing Strategies for Saline Agriculture. 5-6 Sep., Tabriz, Iran. (In Persian with English abstract).

Pirasteh-Anosheh, H. and Y. Emam. 2018b. Modulation of oxidative damage due to salt stress using salicylic acid in Hordeum vulgare. Archiv. Agron. Soil Sci. 64 (9): 1268-1277.

Pirasteh-Anosheh, H., Y. Emam and M. Pessarakli. 2019. Grain filling pattern of Hordeum vulgare as affected by salicylic acid and salt stress.J. Plant Nutr. 42(3): 278-286.

Rademacher, W. 2015. Plant growth regulators: backgrounds and uses in plant production. J. Plant Growth Regul. 34(4): 845-872.

Rajala, A. and P. Peltonen-Sainio. 2001. Plant growth regulator effects on spring cereal root and shoot growth. Agron. J. 93: 936-943.

Ranjbar, G. and H. Pirasteh-Anosheh. 2015. A glance to the salinity research in Iran with emphasis on improvement of field crops production. Iran. J. Crop Sci. 17(2): 165-178. (In Persian with English abstract).

Ranjbar, G. and H. Pirasteh-Anosheh. 2017. Improving the yield of wheat and barley in saline conditions using salicylic acid foliar application. Extension Bulletin. AREEO press, Tehran, Iran. (In Persian).

Ranjbar, G., H. Pirasteh-Anosheh and N. Besharat. 2017. Determination of the optimum concentration and time of salicylic acid foliar application for improving barley growth under non-saline and saline conditions $\mathrm{J}$. Crop Prod. Proces. 22: 61-72. (In Persian with English abstract).

Ranjbar, G., H. Pirasteh-Anosheh, M. H. Banakar and H. R. Miri. 2018. A review on halophytes researches in Iran: explanation of challenges and solutions. Plant Ecophysiol. 32(1): 117-129. (In Persian with English abstract).

Ranjbar, G., F. Dehghani, H. Pirasteh-Anosheh and M. H. Banakar. 2019. Improving salt tolerance threshold of Salicornia bigelovii at germination stage using gibberellic acid pretreatment at different levels of seawater salinity. Iran. J. Range Desert Res. 26(1): 62-72. (In Persian with English abstract).

Rokhafrooz, K., Y. Emam and H. Pirasteh-Anosheh. 2016. The Effect of chlormequat chloride on yield and 


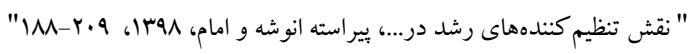

yield components of three wheat cultivars under drought stress conditions. J. Crop Prod. Proces. 20: 111-122. (In Persian with English abstract).

Ryu, H. and Y. G. Cho. 2015. Plant hormones in salt stress tolerance. J. Plant Biol. 58(3): 147-155.

Sade, N., M. del Mar Rubio-Wilhelmi, K. Umnajkitikorn and E. Blumwald. 2017. Stress-induced senescence and plant tolerance to abiotic stress. J. Exp. Bot., 69(4): 845-853.

Saffari, G., I. Alhadadi, S.M.J. Arvin, H. Irannejad, G. Akbari and A. Nemati Ghasemabadi. 2012. Effect of some growth regulators on seed germination characters and seedling primary growth of canola (Brassica napus L.). Iran. J. Seed Sci. Technol. 1(2): 185-192.

Shahbaz, M. and M. Ashraf. 2007. Influence of exogenous application of brassinosteroid on growth and mineral nutrients of wheat (Triticum aestivum L.) under saline conditions. Pak. J. Bot. 39: 513-522.

Shahbaz, M., M. Ashraf and H. R. Athar. 2008. Does exogenous application of 24-epibrassinolide ameliorate salt induced growth inhibition in wheat (Triticum aestivum L.)? Plant Growth Regul. 55: 51-64.

Shakirova, F. M. 2007. Role of hormonal system in the manifestation of growth promoting and anti-stress action of salicylic acid, in: Hayat S., A. Ahmad (Eds.), Salicylic Acid, A Plant Hormone. Springer, Dordrecht, Netherlands.

Shekoofa, A. and Y. Emam, Y. 2008. Effect of nitrogen fertilization and plant growth regulators (PGRs) on yield of wheat. J. Agric. Sci. Tech. 10: 101-108.

Sun, T.P. and F. Gubler. 2004. Molecular mechanism of gibberellin signaling in plants. Annu. Rev. Plant Biol., 55, 197-223.

Suo, H. C., W. Li, K. H. Wang, U. Ashraf, J. H. Liu, J. G. Hu, Z. J. Li, X. L. Zhang, J. Xie and J. R. Zheng. 2017. Plant growth regulators in seed coating agent affect seed germination and seedling growth of sweet corn. Appl. Ecol. Environ. Res. 15(4): 829-839.

Ungar, I. A., 1977. Salinity, temperature, and growth regulator effects on seed germination of salicornia europaea L. Aqu. Bot. 3: 329-335.

Vahabi, N., Y. Emam, and H. Pirasteh-Anosheh. 2016. Improving wheat growth and yield using chlormequat chloride, salicylic acid and jasmonic acid under water stress. Iran. J. Field Crops Res. 15(1): 124-135. (In Persian with English abstract).

Wang, X. L., X. Wang, H. Cao and W. W. Zhang. 2010. Effects of humic acid seed-coating on seed germination and seedling growth of maize in water stress. J. Maize Sci. 4: 96-98.

Yun-xia, G., Z. Li-jun, L. Feng-hai, C. Zhi-bin, W. Che, Y. Yun-Cong, H. Zhen-hai, Z. Jie and S. Zhensheng. 2010. Relationship between jasmonic acid accumulation and senescence in drought-stress. Afric. J. Agric. Res. 5: 1978-1983.

Zhu, Y. L. and X. Wang. 2013. Effects of salicylic acid seed-coating on seed germination and seedling growth in maize under low temperature stress. J. Maize Sci. 21(4): 68-71. 


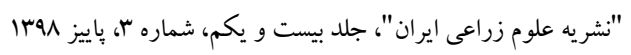

\title{
The role of plant growth regulators in enhancing crop yield under saline conditions: from theory to practice
}

\section{Pirasteh-Anosheh, H. ${ }^{1}$ and Y. Emam ${ }^{2}$}

\begin{abstract}
Pirasteh-Anosheh, H. and Y. Emam. 2019. The role of plant growth regulators in enhancing crop yield under saline conditions: from theory to practice. Iranian Journal of Crop Sciences. 21(3): 188-209. (In Persian).

Intensified salinization of water and soil resources has promoted interest for research and approaches of improving crop yield under saline conditions. Reviewing the literature showed that the records on understanding of different aspects of salt stress and enhanced salinity tolerance in the world goes back to more than a century. Different approaches have been suggested to increase crop yield under saline conditions, among which one is using plant growth regulators (PGRs). Application of PGRs has begun since 1930s and their global annual sales are about US\$ 1.2 billion. Nearly 40 active ingredients og PGRs are now in use, applied either as a single or combined treatments, among which the most important are auxins, cytokinins, gibberellins, ethylene, abscisic acid, brassinosteroids, salicylic acid, chlormequat chloride, paclobutrazol, jasmonic acid, ascorbic acid, triacontanol, strigolactones, nitric oxide, polyamines and plant peptide hormones. There have been large body of reports showing quantitative and quality improvement of crops as well as salinity tolerance as the consequences of PGRs application.However, most of these studies were conducted under controlled conditions (i.e. out of field conditions), as one season experiments, and this makes the results unreliable. In this paper, with having in mind the applicability for the field conditions, crop yield improvement as the result of using PGRs has been reviewed.
\end{abstract}

Key words: Phytohormones, Salinity stress, Seed priming and Stress tolerance.

Received: March, $2019 \quad$ Accepted: September, 2018

1. Assistant Prof., National Salinity Research Center, Agricultural Research, Education and Extension Organization, Yazd, Iran (Corresponding author) (Email: h.pirasteh.a@gmail.com)

2. Professor, Faculty of Agriculture, Shiraz University, Shiraz, Iran 